\title{
Relationships between topography and spatial variations in groundwater and soil morphology within the Taoyuan-Hukou Tableland, Northwestern Taiwan
}

\author{
Yu-Shih Lin ${ }^{\mathrm{a}}$, Yi-Wen Lin ${ }^{\mathrm{b}}$, Yu Wang ${ }^{\mathrm{a}}$, Yue-Gau Chen ${ }^{\mathrm{a}, *}$, Mei-Ling Hsu ${ }^{\mathrm{b}}$, \\ Shou-Hao Chiang ${ }^{b}$, Zueng-Sang Chen ${ }^{c}$ \\ a Department of Geosciences, National Taiwan University, Taipei 106, Taiwan, ROC \\ ${ }^{\mathrm{b}}$ Department of Geography, National Taiwan University, Taipei 106, Taiwan, ROC \\ ${ }^{c}$ Department of Agricultural Chemistry, National Taiwan University, Taipei 106, Taiwan, ROC
}

Received 29 August 2006; received in revised form 27 December 2006; accepted 10 January 2007

Available online 25 January 2007

\begin{abstract}
This study examines the relationships between topography and spatial variations in groundwater and soil morphology within the multi-step Taoyuan-Hukou Tableland in northwest Taiwan. Several different geomorphological and pedological approaches were jointly undertaken, including analyses of a digital elevation model (DEM), a reclassified soil map, field survey results, engineering borehole data, and a hydrological simulation. Five major geomorphic surfaces were identified based on terrace scarps observed in the DEM; minor surfaces separated by small fluvial scarps or tectonic scarps were also mapped. The simplified soil map and field study of soil morphology reveal a number of soil-distribution patterns associated with specific topographic settings. Soil morphology changes from homogeneous red soils in the fore-edge of surfaces to mottled soils and finally to gley soils in back-edge regions. Such a pattern is more pronounced in the proximal part of a surface, while toward the distal zone the patterns tend to be obscured by increasing amounts of mottled and gley soils. The proportion of homogeneous soils increases with narrowing of the surface. For fan-shaped surfaces, soil types appear to be dominated by mottled soils except for at terrace edges, where homogeneous red soils occur. While homogeneous soils dominate tectonically elevated surfaces, a toposequence of homogeneousmottled-gley soils occurs in the surrounded lowlands. Borehole data and hydrological models indicate that these soil-distribution patterns are strongly related to groundwater occurrence and fluvial processes, both of which are generally governed by topography. Despite the observed pedodiversity in this area, the common feature of these toposequences, i.e., the distribution of homogeneous red soils along the surface fore-edge, may serve as a basis for establishing a reliable soil chronosequence for the area.
\end{abstract}

(C) 2007 Elsevier B.V. All rights reserved.

Keywords: Groundwater table; Geomorphic surface; Soil morphology; Soil toposequence; Wetness index

\footnotetext{
* Corresponding author. Tel.: +88622369 7648; fax: +88622363 6095 .

E-mail address: ygchen@ntu.edu.tw (Y.-G. Chen).
}

\section{Introduction}

This paper presents a synthesis of the interplay among soil development, topography and hydrological processes in a complex geological and geomorphological setting. The study area, the Taoyuan-Hukou Tableland, is located 
in northwest Taiwan at approximately $24^{\circ} 45^{\prime}-25^{\circ} 10^{\prime} \mathrm{N}$ and $120^{\circ} 50^{\prime}-121^{\circ} 25^{\prime} \mathrm{E}$ (Fig. 1). The tableland was originally an alluvial fan created by the paleo-Tahan River. Late Quaternary tectonic activity has resulted in a clockwise migration of the paleo-Tahan River and the active fan lobe with the concurrent entrenchment of the alluvial system (Huang, 1995; Wang et al., 2002; Chen et al., 2003). The paleo-Tahan River was finally captured by the paleo-Tanshui River at ca. $30 \mathrm{ka}$ (Chen and Liu, 1991). The geological structures accompanying the tectonic activity extend through different levels of the original terrace flats and generate intricate topographic features. The intimate relationship between the active geological situation and the geomorphological characteristics has made the Taoyuan-Hukou Tableland an intriguing region for morphotectonic and geochronological studies (e.g., Teng et al., 2003; Wang, 2003; Watanuki et al., 2005).

Fluvial and marine terraces are considered suitable materials to investigate soil chronosequences (Bockheim et al., 1996; Marcos and Frances, 1997; Birkland, 1999; Muhs, 2001), as in many cases variables other than time can be held approximately constant. In Taiwan, soil chronosequences have been established for marine terraces along the east coast of the island (Tsai et al., in press-a) and river terraces of the Pakua Tableland in the Western Foothills (Tsai et al., 2006, 2007, in press-b). As suggested by these studies, in the absence of neotectonic activity that generates intra-surface topographic variations, spatial variations in soil properties within the same morphogenetic surface may be ignored. In contrast, concerning the complex topography of the TaoyuanHukou Tableland, the relationship between soil properties and terrace ages is less straightforward. Although Lin (1991) and Wada (2004) have constructed chronosequences for this area using soils retrieved from terrace edges, Lin et al. (2005) reported that soils on the $30 \mathrm{kyr}-$ old Taoyuan Terrace ("surface A" in the present text), even along the terrace edge, are variable in terms of morphology. The variation was explained by differential drainage of soils in a paleo-fluvial landscape. Their observation brings into question whether soils on the other older, tectonically deformed surfaces in the TaoyuanHukou Tableland are also morphologically variable. A recent study in Europe has also reported a spatial diversity in soils developed upon terraces ranging in age from the early Pleistocene to the Holocene (Saldaña and Ibáñez, 2004). Information on the pedodiversity can therefore provide insight into the development of soil chronosequences within this complex geomorphic setting.

We use combined geomorphological and pedological approaches to examine the spatial variability of soils within the Taoyuan-Hukou Tableland. The topography of this area was examined from a digital elevation model (DEM) and fieldwork, while groundwater hydrology was analyzed from engineering borehole data and a model simulation. A preliminary distribution of variations in soil morphology was obtained by reclassifying the published soil map of the Taoyuan-Hukou Tableland, and data concerning morphological characteristics were collected during fieldwork and from previously published reports. These two lines of evidence were then integrated to facilitate a discussion of the relationships among topography, hydrology and pedodiversity.

\section{Regional setting}

Taiwan is located at the convergent boundary between the Philippine Sea Plate and the continental margin of the Eurasian Plate, which is actually the junction of two reversed-polarity subduction systems (Suppe, 1981; Fig. 1a). To the south of Taiwan, the seafloor of the South China Sea underplates the Philippine Sea Plate along the Manila Trench, generating the $\mathrm{N}-\mathrm{S}$ trending Luzon Arc upon the Philippine Sea Plate. In turn, the Philippine Sea Plate is moving northwestward and underplates the Eurasian Plate along the Ryukyu Trench to the east of Taiwan. Because the Philippine Sea Plate continues to move and subduct, the gigantic mass of the Luzon Arc seated upon the plate is forced into collision with the continental margin, leading to the formation of a mountain belt. This collision began at 5-6 Ma and has generated a fold-and-thrust belt that is the current Taiwan Island (Ho, 1986; Teng, 1990). Accordingly, a strong geotectonic stress directed from the southeast is currently recorded from central Taiwan. In contrast, north Taiwan is currently experiencing a postcollision stage because of southward migration of the collision zone since 5-6 Ma. In addition, back-arc rifting is occurring within the Ryukyu Arc system, whose geomorphic expression is the Okinawa Trough. This rifting has gradually migrated into northern Taiwan, as collision-related compression has largely ceased in this area (Lu et al., 1995; Teng, 1996).

The Taoyuan-Hukou Tableland is located close to the transition zone between the two geotectonic stress systems described above (Teng and Lee, 1996). The rate of horizontal displacement in this area, as revealed by recent GPS measurements, is just $2-6 \mathrm{~mm} \mathrm{yr}^{-1}$ northwestward, a relatively lower rate recorded in Taiwan (Yu et al., 1997). Despite the relative stability of this region, several active tectonic structures have been identified. The tableland consists of Pleistocene conglomerates and sandstones overlain uncomformably by lateritic terrace deposits (Fig. 1b). Based on terrace 

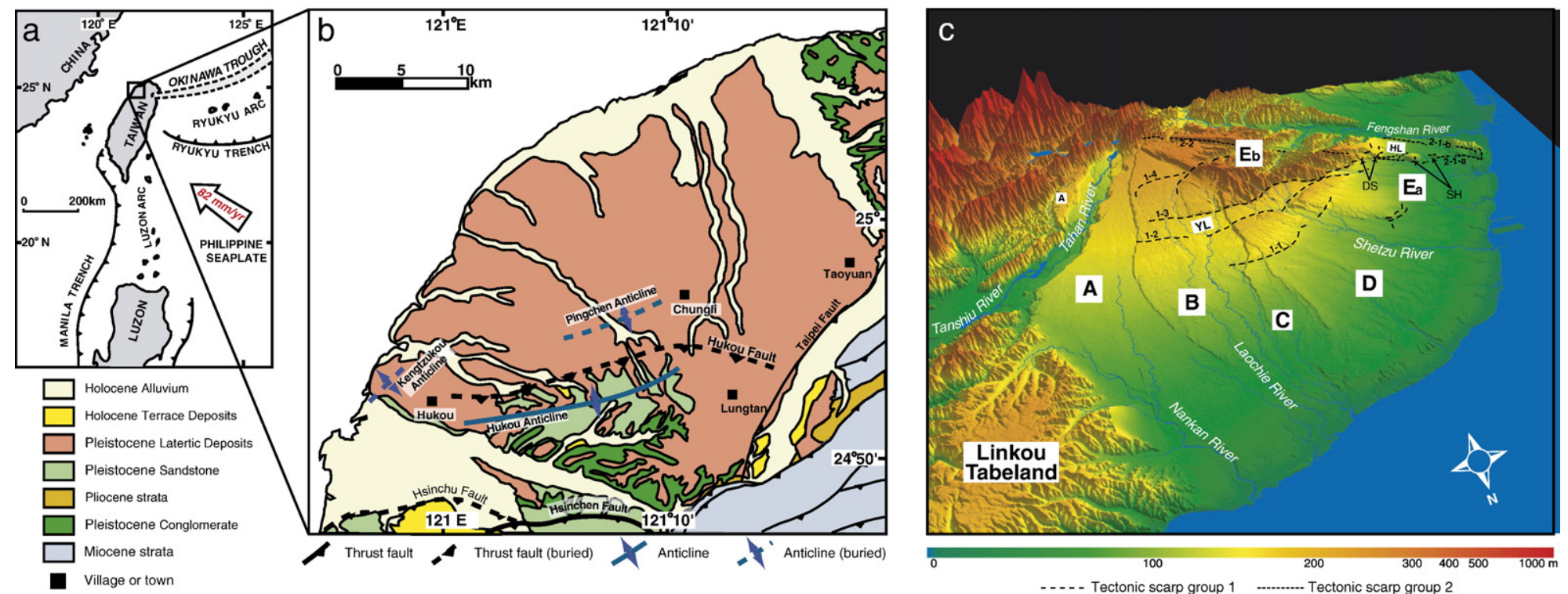

Fig. 1. Location map of the study area. The Taoyuan-Hukou Tableland, located in northwestern Taiwan (a), consists of Pleistocene conglomerate/sandstone overlain uncomformably by the lateritic terrace deposits (b). The main structures that stretch across the terrace flats are the Hukou and the Pingchen anticlines and the Hukou Fault. (c) The 3-D relief of the Taoyuan-Hukou Tableland. A-E $E_{b}$ : major geomorphic surfaces. YL: Yangmai Lowland; HL: Hukou Lowland. DS: displaced scarps; SH: small hills. 
correlation, the Pleistocene strata of the TaoyuanHukou Tableland were likely deposited during a period coeval or younger than the nearby Linkou Tableland (Fig. 1c), which is older than $400 \mathrm{ka}$ (Wei et al., 1998). Except the radiocarbon age of ca. $30 \mathrm{ka}$ from the youngest "surface A" (Chen and Liu, 1991), there are no published reliable ages so far for the terrace surfaces. Their chronological order is basically determined by their descending elevations in the clockwise direction (Huang, 1995; Wang, 2003). Mineralogical studies have shown that there are significant amounts of illite, vermiculite and other intercalated clay minerals in the quartz-dominant lateritic deposits, implying limited degree of laterite development (Lin, 1991; Wada, 2004). The main structures that deform the terrace flats are the ENE-trending Hukou and Pingchen Anticlines and the dome-like Kengtzukou Anticline, all of which developed from the main detachment as it migrated westward (Suppe, 1983). The Hukou fault is probably the hinge-break fault in the forelimb of the Hukou anticline (Wang, 2003).

Climate data recorded over the past decade (19962005) show a mean air temperature of $28^{\circ} \mathrm{C}$ in summer and $14{ }^{\circ} \mathrm{C}$ in winter, while the mean annual rainfall is around $2000 \mathrm{~mm}$ (Taiwan Central Weather Bureau, 1996, 1997, 1998, 1999, 2000, 2001, 2002, 2003, 2004, 2005). Monthly rainfall in winter is much lower than that in other seasons. Annual rainfall exceeds annual evapotranspiration, resulting in generally humid conditions. The soil-temperature and moisture regimes are hyperthermic and udic, respectively. Most of the agricultural land on the Taoyuan-Hukou Tableland has been plowed as paddy fields since the construction of irrigation systems and reservoirs in the 1950s. These soils are seasonally flooded by irrigation water that generally perches above the shallow plowed zone and does not significantly influence the B horizon (Jien et al., 2004).

\section{Materials and methods}

\subsection{Identification of geomorphic features and ground- water analysis}

We used the Geographic Information System software ArcView 3.2 to identify morphotectonic features based the DEM (in $40 \times 40 \mathrm{~m}$ resolution) and generate topographic profiles for the construction of geological cross-sections. Identified topographic features were then checked in the field. Engineering borehole data archived at the Central Geological Survey in Taiwan (available at http://210.69.81.69/geo/begin_internet.cfm/) were used to construct geological cross-sections and determine the distribution of the groundwater table in the study area. These boreholes were drilled to a depth of 10 to $20 \mathrm{~m}$ during different seasons, and the reconstructed groundwater table thus represents a snapshot of the unconfined aquifer. According to previous studies that undertook hydrological monitoring of groundwater in the coastal area of the Taoyuan-Hukou Tableland, the seasonal fluctuation in the groundwater level is $\sim 2 \mathrm{~m}$ (Hseu and Chen, 2001; Jien et al., 2004). Accordingly, a drop of more than $2 \mathrm{~m}$ in the level of the reconstructed groundwater table is probably related to factors other than seasonality.

We performed a model simulation to obtain data for the Yangmai and Hukou Lowlands (Fig. 2b), for which engineering borehole data are limited. The soil wetness condition is a result of complex interactions among topography, precipitation, evaporation, water movement, and soil permeability; consequently, it varies significantly over space. The dimensionless wetness index (also termed the topographic wetness index), $w$, is written as

$w=\ln \left(\frac{a}{\tan \beta}\right)$,

where $a$ is the specific catchment area defined as the upslope area per unit width of contour, and $\tan \beta$ (dimensionless) is the gradient of the given cell. This index, first proposed by Beven and Kirkby (1979) as a composite indicator of specific catchment area and slope gradient, is widely used as a proxy of approximate local wetness (e.g., Lin et al., 2006). Higher $w$ values usually correspond to higher local soil-water content. Based on the DEM data, we adopted the infinite flow direction algorithm proposed by Tarboton (1997), which achieves a better drainage configuration when using rasterized topographic data (Zhou and Liu, 2002) to calculate the specific catchment area. Thereafter, we used ArcView to derive the slope and subsequently the topographic index of individual grid cells.

\subsection{Reclassification of soil map and field investigations}

A number of different methods can be used to characterize pedodiversity at different scales of terrace topography. Some of these techniques involve the analysis of pedodiversity via dimensionless indexes (Ibáñez et al., 1994; Saldaña et al., 1998; Phillips, 2001; Saldaña and Ibáñez, 2004; Toomanian et al., 2006) or the development of pedofacies models (BullingerWeber and Gobat, 2006). These techniques, which 

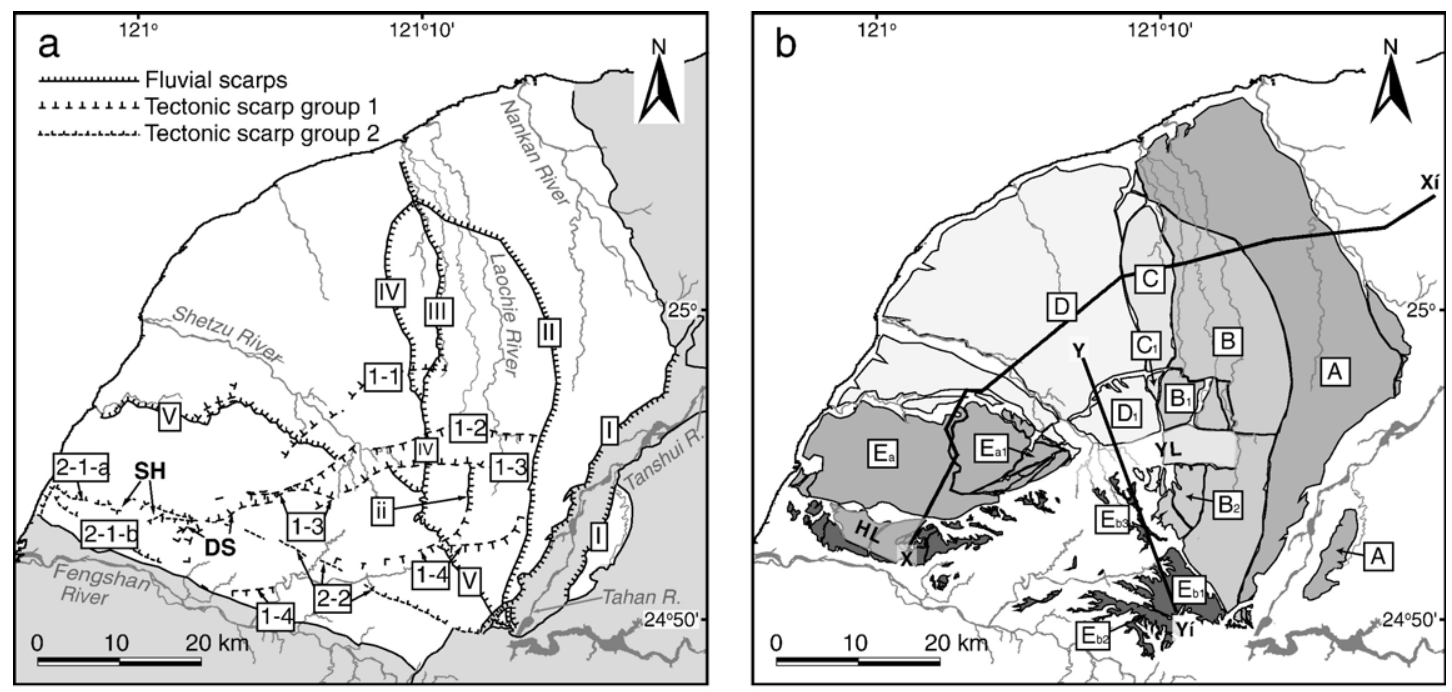

C

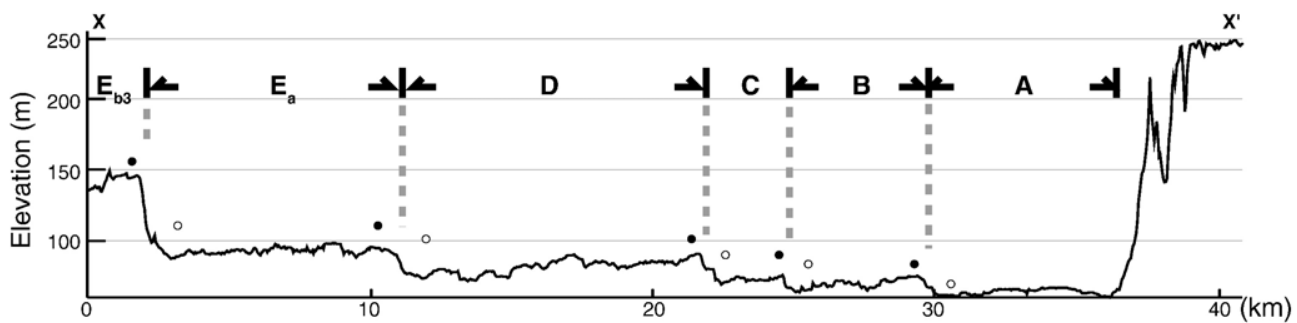

d

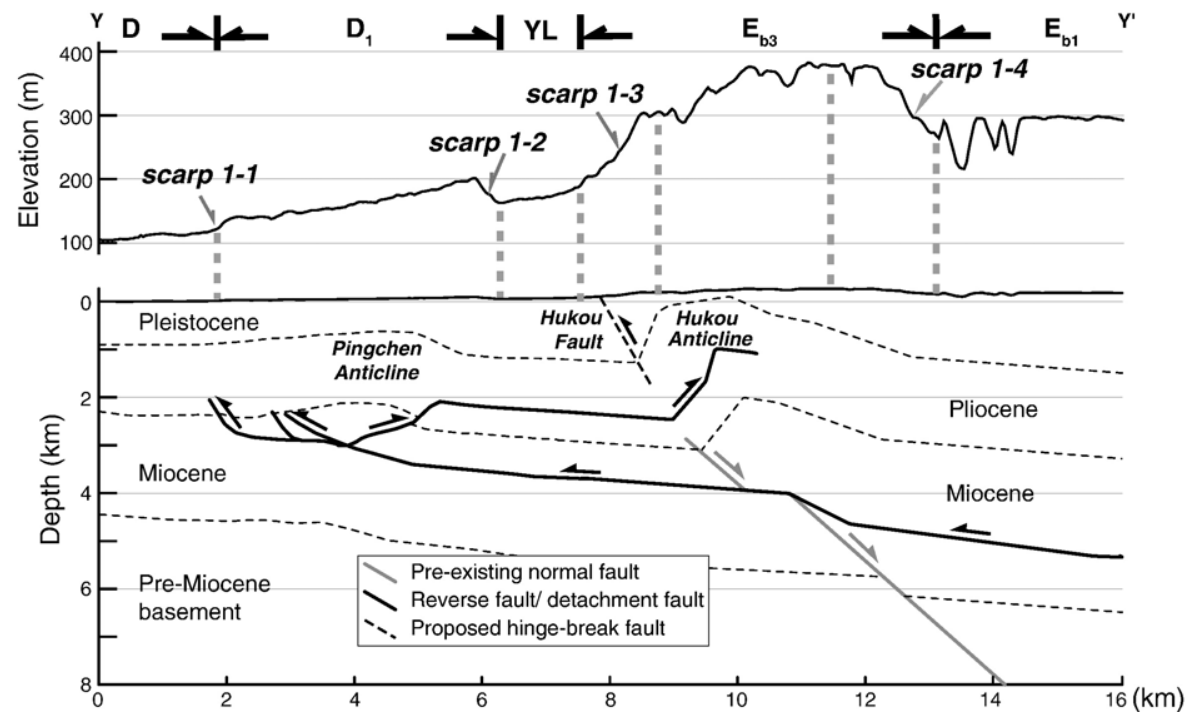

Fig. 2. Geomophology of the Taoyuan-Hukou Tableland. (a) Topographic features of the tableland. I to V denote the major fluvial scarps, while ii indicates a minor fluvial scarp existing between scarps II and III. The tectonic scarps are divided into the ENE-trending group one (1-1 to 1-4) and WNW-trending group two (2-1 and 2-2). Scarp 2-1 is further divided into two subgroups (2-1-a and 2-1-b). DS: displaced scarps; SH: small hills. (b) Landform units of the tableland. Capital letters mark major surfaces with fluvial scarps as terrace boundaries, and subscripts labels mark secondary geomorphic surfaces created mainly by tectonic processes. YL: Yangmai Lowland; HL: Hukou Lowland. (c) Topographic profile X-X', showing the descending steps from surface $\mathrm{E}_{\mathrm{b} 3}$ to surface $\mathrm{A}$. Solid dots and open circles denote locations of fore-edge and back-edge on each surface, respectively, according to the definitions of Woods (1980). The location of the profile is shown in (b). (d) Topographic profile $\mathrm{Y}-\mathrm{Y}^{\prime}$ and the corresponding simplified geologic section. The location of the profile is shown in (b). 
provide a quantitative assessment of pedodiversity over a complete terrace system, are informative when comparing soils from a series of geomorphic surfaces. However, detailed information on the soil distribution is lost when exploring the topological relationship between pedons and topographic features.

In the present study, we adopted the method of soil map reclassification, which has proved useful in assessing spatial variations in soil morphology with respect to topography ( $\mathrm{Lin}$ et al., 2005). The 1:25000 soil map (Chen, 1976) used in this study has been described in our previous work (Lin et al., 2005). We grouped the 62 soil types that are used in the soil map of the Taoyuan-Hukou Tableland on the basis of morphological properties, including soil thickness, color, mottling, soil depth of Fe-Mn concretions, plinthite, and texture. In this way, we identified a total of nine major categories (Table 1). In addition to the seven major groups (Nos. 1-7 in Table 1) outlined in Lin et al. (2005), two new categories are newly reported in this paper. Group No. 8, sandy soils distributed along the coast, is distinct from other clayey soils. Group No. 9 , soils coded as MR in the soil map, is a complex of soils formed upon terrace scarps. The common characteristic of the soils is a thin soil profile due to strong erosion at the site (Chen, 1976). Consequently, the distribution of MR soils is a useful indicator of the locations of scarps. The simplified soil map was georeferenced and overlain on the DEM-derived shaded relief map within ArcView to enable a direct comparison of the two maps.

Soil samples were collected from 30 sites by handauger drilling to a depth of 1-2 $\mathrm{m}$. Following the criteria of Schoeneberger et al. (1998), we described soil thickness, color, mottling, texture, structure, and consistency within each profile. Soil samples were taken from each horizon for morphological comparison and archive purposes. Previously published fieldmorphology data (Lin, 1991; Lin et al., 2005) were also collated to establish a more complete database.

\section{Characteristics of geomorphic features}

\subsection{Terrace scarps}

The Taoyuan-Hukou Tableland consists of dissected relics of flat to gently inclined paleosurfaces of variable width (Fig. 2). Scarps of both fluvial and tectonic origin form the boundaries of these paleosurfaces. Based on scarp morphology and orientation, we identified five major (I-V) fluvial scarps and one minor scarp (ii) existing between scarps II and III (Figs. 1 and 2). These scarps are characterized by remarkable relief in the proximal part of the paleofan but gradually diminish in relief toward the distal fan area. The orientations of the scarps are generally parallel to the direction of the paleoTahan River at its different stages.

We identified two groups of tectonic scarps (Fig.2a). The first group, which trends ENE, comprises four main tectonic scarps (1-1 to 1-4). On the basis of a comparative analysis of surface topographic features and a subsurface structural contour map, Chen et al. (2003) proposed that these features are related to two asymmetric fault-related folds. Scarps 1-1 and 1-2 are associated with the kink-bend growth of the Pingchen Anticline, while scarps 1-3 and 1-4 are developed in the same manner as the forelimb and backlimb of the Hukou Anticline (Fig. 2d). The second group of tectonic scarps occurs discontinuously in the southwestern part of the study area. We divided these landforms into western and eastern subgroups (2-1 and $2-2)$. Subgroup 2-1 contains complicated landforms in addition to the two sets of tectonic scarps that converge toward the coastal area. The small hills, or the inferred pressure ridges, and the displaced scarp 1-3 (Figs. 1c and $2 \mathrm{a}$ ) indicate the presence of a right-lateral fault in subgroup 2-1-a. Subgroup 2-1-b contains several segments of tectonic scarps that are considered to represent the remnants of a single scarp. The tectonic scarps in subgroup 2-2, having an identical orientation to those in subgroup 2-1-a, may be part of the dextral fault system. The fact that this structure heads offshore suggests that it is a tear fault between the structures of the Tableland and unidentified structures offshore (Shyu et al., 2005).

\subsection{Landform units}

A number of different naming systems have been proposed for terraces on the Taoyuan-Hukou Tableland, with the different systems being based on terrace altitude, terrace boundary morphology, distribution patterns of fluvial landforms, or the properties of red soil (Lin, 1957; Ku, 1963; Sun-Lin, 1982; Yang, 1986; Chen, 1988; Teng et al., 2003). In the present study, we avoided the traditional LH/LT (lateritic highland/ lateritic terrace) nomenclature to avoid confusion in the definition of LH/LT and the inconsistent numbering order employed by different authors (Table 2). Instead, we used capital letters to label major surfaces with fluvial scarps as terrace boundaries, and subscripts to label secondary geomorphic surfaces created mainly by tectonic processes (Fig. 2b). Surfaces A, B, C, and D are widely considered to be the youngest four terraces of the study area, but classification of the remaining surfaces is 
Table 1

Reclassification of soil series on the Taoyuan-Hukou Tableland (modified after Lin et al., 2005)

\begin{tabular}{|c|c|c|c|c|c|c|c|c|c|}
\hline \multicolumn{2}{|c|}{ Reclassification } & \multicolumn{8}{|l|}{ Classification by Chen (1976) } \\
\hline \multirow[t]{2}{*}{ No. } & \multirow[t]{2}{*}{ Group } & \multirow[t]{2}{*}{ Profile characteristics } & \multirow[t]{2}{*}{ Color } & \multirow[t]{2}{*}{ Texture } & \multirow[t]{2}{*}{$\begin{array}{l}\text { No Fe-Mn } \\
\text { concretions }^{\mathrm{a}}\end{array}$} & \multicolumn{2}{|c|}{$\begin{array}{l}\text { Soil depth to } \\
\text { the Fe-Mn } \\
\text { concretions }\end{array}$} & \multirow[t]{2}{*}{ Plinthite } & \multirow[t]{2}{*}{$\begin{array}{l}\text { High } \\
\text { organic } \\
\text { content }^{\mathrm{a}}\end{array}$} \\
\hline & & & & & & $<60 \mathrm{~cm}$ & $>60 \mathrm{~cm}$ & & \\
\hline 1 & $\begin{array}{l}\text { Homogeneous } \\
\text { red soils }\end{array}$ & $40-120 \mathrm{~cm}$ : homogeneously red & $\mathrm{R}$ & $\begin{array}{l}\mathrm{SiC} \text { to } \\
\mathrm{CL}\end{array}$ & $\mathrm{Pc}, \mathrm{Lk}$ & $\mathrm{Sh}, \mathrm{Tu}$ & $\begin{array}{l}\mathrm{Ce}, \mathrm{Tz} \\
\mathrm{Yc}\end{array}$ & - & - \\
\hline 2 & $\begin{array}{l}\text { Homogeneous } \\
\text { orange soils }\end{array}$ & Yellowish red & YR & $\mathrm{SiC}$ & $\mathrm{Tc}$ & - & - & - & - \\
\hline 3 & $\begin{array}{l}\text { Homogeneous } \\
\text { yellow soils }\end{array}$ & $\begin{array}{l}\text { Yellowish brown } \\
<60 \mathrm{~cm} \text { : with few red clods }\end{array}$ & YB & $\mathrm{SiCL}$ & $\mathrm{Cl}, \mathrm{Lt}$ & - & - & $\mathrm{Hi}, \mathrm{Hw}$ & - \\
\hline \multirow[t]{2}{*}{4} & $\begin{array}{l}\text { Mottled red } \\
\text { soils }\end{array}$ & $\begin{array}{l}<90 \mathrm{~cm} \text { : red } \\
>90 \mathrm{~cm} \text { : red matrix with yellow, } \\
\text { and brown mottles }\end{array}$ & $\begin{array}{l}\mathrm{R} \mathrm{R}+ \\
\mathrm{YB}\end{array}$ & $\begin{array}{l}\mathrm{SiC} \text { to } \\
\mathrm{SiCL}\end{array}$ & $\mathrm{Tl}$ & - & $\mathrm{Nt}$ & - & - \\
\hline & & $\begin{array}{l}\text { Below the topsoil: red matrix with } \\
\text { a few yellowish brown mottles }\end{array}$ & R YB & $\begin{array}{l}\mathrm{SiC} \text { to } \\
\mathrm{SiCL}\end{array}$ & $\mathrm{Hk}$ & - & $\mathrm{Kt}, \mathrm{Hu}$ & - & - \\
\hline \multirow[t]{3}{*}{5} & $\begin{array}{l}\text { Mottled yellow } \\
\text { soils }\end{array}$ & $\begin{array}{l}<60 \mathrm{~cm} \text { : yellowish brown } \\
>60 \mathrm{~cm} \text { : red clods more than yellowish } \\
\text { brown clods }\end{array}$ & $\begin{array}{l}\mathrm{YB}(\mathrm{YR}) \\
\mathrm{R}+\mathrm{YB}\end{array}$ & $\mathrm{SiCL}$ & $\mathrm{Tw}$ & $\mathrm{Pp}$ & - & - & - \\
\hline & & $\begin{array}{l}<60 \mathrm{~cm} \text { : yellowish brown } \\
>60 \mathrm{~cm} \text { : red clods fewer than yellowish } \\
\text { brown clods }\end{array}$ & $\begin{array}{l}\mathrm{YB} \\
\mathrm{R}+\mathrm{YB}\end{array}$ & $\mathrm{SiCL}$ & $\mathrm{Lc}$ & - & - & $\mathrm{Cw}$ & - \\
\hline & & $\begin{array}{l}\text { Below the topsoil: yellow matrix with } \\
\text { a few red brown mottles }\end{array}$ & $\begin{array}{l}\text { YB R+ } \\
\text { YB }\end{array}$ & $\mathrm{SiCL}$ & $\mathrm{Ka}$ & - & - & - & - \\
\hline \multirow[t]{4}{*}{6} & Gley soils & $\begin{array}{l}\text { Yellowish brown and gray with a few } \\
\text { red clods }\end{array}$ & $\begin{array}{l}\mathrm{YB}+\mathrm{W}+ \\
\mathrm{R}(\mathrm{YR})\end{array}$ & $\mathrm{SiCL}$ & Fs & - & - & $\mathrm{Pu}$ & - \\
\hline & & $>60 \mathrm{~cm}$ : yellowish brown and gray & $\begin{array}{l}\mathrm{YB} / \mathrm{YB}+ \\
\mathrm{W}\end{array}$ & $\begin{array}{l}\mathrm{SiCL} \\
\text { to } \mathrm{CL}\end{array}$ & $\mathrm{Mt}, \mathrm{Tk}$ & - & - & $\mathrm{Si}$ & $\mathrm{Cu}, \mathrm{Pa}$ \\
\hline & & $<60 \mathrm{~cm}$ : yellowish brown and gray & $\mathrm{YB}+\mathrm{W}$ & $\begin{array}{l}\text { SiC to } \\
\mathrm{SiL}\end{array}$ & $\mathrm{Tn}, \mathrm{Ct}$ & - & - & $\mathrm{Hh}$ & - \\
\hline & & $\begin{array}{l}\text { Yellowish brown and gray; reworked } \\
\text { soil as parent material }\end{array}$ & $\mathrm{YB}+\mathrm{W}$ & SL & Yk & - & - & $\mathrm{Ft}$ & $\mathrm{Nm}, \mathrm{Pd}$ \\
\hline \multirow[t]{4}{*}{7} & Reworked soils & $\begin{array}{l}\text { Red to yellowish brown; } \\
\text { truncated profile } \\
>50 \mathrm{~cm} \text { : reach cobbles }\end{array}$ & $\mathrm{YB}(\mathrm{R})$ & $\begin{array}{l}\text { CL to } \\
\mathrm{SiCL}\end{array}$ & $\mathrm{Ci}, \mathrm{Sf}$ & - & - & - & - \\
\hline & & $\begin{array}{l}\text { Red to yellowish brown; } \\
\text { truncated profile; clayey to sandy } \\
<50 \mathrm{~cm} \text { : reach cobbles }\end{array}$ & $\mathrm{YR}(\mathrm{R})$ & $\begin{array}{l}\text { CL to } \\
\text { SCL }\end{array}$ & $\mathrm{Sa}, \mathrm{Yp}$ & - & - & - & - \\
\hline & & $\begin{array}{l}\text { Dark yellow to yellowish brown; } \\
\text { reworked soil as parent material } \\
>50 \mathrm{~cm} \text { : reach cobbles }\end{array}$ & $\begin{array}{l}\mathrm{Y}(\mathrm{YR}) \\
\text { to } \mathrm{YB}\end{array}$ & $\begin{array}{l}\text { CL to } \\
\text { SL }\end{array}$ & $\begin{array}{l}\mathrm{Ck}, \mathrm{Hg}, \mathrm{Kw}, \mathrm{Ks}, \mathrm{Na} \\
\mathrm{Sp}, \mathrm{Tg}, \mathrm{Wk}\end{array}$ & Ip & $\mathrm{Nl}$ & - & Cs \\
\hline & & $\begin{array}{l}\text { Dark yellow to yellowish brown; } \\
\text { reworked soil as parent material } \\
<50 \mathrm{~cm} \text { : reach cobbles }\end{array}$ & $\begin{array}{l}\mathrm{Y}(\mathrm{YR}) \\
\text { to } \mathrm{YB}\end{array}$ & $\begin{array}{l}\text { SiL to } \\
\text { SL }\end{array}$ & Cn, Hn, Ns, Sk, So & - & - & - & - \\
\hline \multirow[t]{2}{*}{8} & Sandy soils & $40-120 \mathrm{~cm}$ : homogeneously red & $\mathrm{R}$ & SL & $\mathrm{Kz}$ & - & - & - & - \\
\hline & along the coast & Yellowish brown+gray; sandy & $\mathrm{YB}+\mathrm{W}$ & $\mathrm{L}$ to $\mathrm{SL}$ & $\mathrm{Ht}, \mathrm{Nc}, \mathrm{Nh}, \mathrm{Ts}$ & - & - & - & - \\
\hline 9 & $\begin{array}{l}\text { Soils on terrace } \\
\text { scarps }\end{array}$ & Complex properties & - & $\mathrm{L}$ to SL & MR & & - & - & - \\
\hline
\end{tabular}

${ }^{\text {a }}$ High organic content: soil series with organic matter higher than $5 \%$ in the top $50 \mathrm{~cm}$ of the standard profiles (Chen, 1976).

controversial. We propose that the remaining surfaces share the same depositional age because they share the same terrace riser (scarp V in Fig. 2a). Surface E is further divided into groups $E_{a}$ and $E_{b}$ because they have distinct tectonic-influenced elevations. Secondary geomorphic surfaces identified within surfaces $B, C, D, E_{a}$, and $\mathrm{E}_{\mathrm{b}}$ are labeled with subscript numbers. Those areas surrounded by tectonically elevated highlands are not included in the classification system. We use the term Yangmei Lowland to describe the area bordered by tectonic scarps 1-2 and 1-3, and arbitrarily divided this area into eastern and western parts because the lowland 
Table 2

Comparison of classification systems for the landscape units in the Taoyuan-Hukou Tableland

\begin{tabular}{|c|c|c|c|c|c|c|c|}
\hline Surface & $\operatorname{Lin}(1957)^{a}$ & $\mathrm{Ku}(1963)$ & Sun-Lin (1982) & Yang (1986) & Chen (1988) & Teng et al. (2003) & This study \\
\hline Kuanhsi & LH & LTY-1a & LH & $\mathrm{LHb}$ & $\mathrm{LHb}$ & $\mathrm{LHb}$ & $\mathrm{E}_{\mathrm{b} 2}$ \\
\hline \multirow[t]{3}{*}{ Tientzuhu } & & LTY-1b & & LHa & LHa & $\mathrm{LHa}$ & $\mathrm{E}_{\mathrm{b} 3}$ \\
\hline & & LTY-2 & & & & LT1b & \\
\hline & & LTY-3b & & & & & \\
\hline Tunglochuan & LT1 & LTY-3a & & LT1a & LT5a & LT1a & $\mathrm{E}_{\mathrm{b} 1}$ \\
\hline Pokungkang & $\mathrm{LH}$ & LTY-3b & LT1 & LT1b & LT5 & LT1c & $\mathrm{E}_{\mathrm{a} 2}$ \\
\hline Pingchen & & LTY-4 & LT2 & LT2 & LT4 & LT2 & $\mathrm{D}_{2}$ \\
\hline Fukang & LT2 & LTY-3b & LT1 & LT1b & LT5b & LT1c & $\mathrm{E}_{\mathrm{a} 1}$ \\
\hline Yangmei & & LTY-4 & LT2 & LT2 & LT4 & LT2 & $\mathrm{D}_{1}$ \\
\hline Talun & & LTY-5 & LT3 & LT3 & LT3 & LT3 & $\mathrm{C}$ \\
\hline Chungli & & LTY-6 & LT4 & LT4 & LT2 & LT4 & B \\
\hline Taoyuan & LT3 & LTY-7a & LT5 & LT5 & LT1 & LT5 & $\mathrm{A}$ \\
\hline
\end{tabular}

${ }^{\text {a }} \mathrm{LH}=$ lateritic highland. $\mathrm{LT}=$ lateritic terrace.

is dissected by terrace scarp IV. The area bordered by subgroups 2-1-a and 2-1-b is termed the Hukou Lowland. Both the elevated surfaces and the lowlands are tilted with slopes ranging from 1 to $4 \%$.

\section{Spatial variations in soil morphology}

\subsection{Spatial patterns in soil morphology inferred from the soil map}

The simplified soil map of the Taoyuan-Hukou Tableland (Fig. 3) demonstrates the following characteristics of the major terraces.

1) The systematic variation in soil morphology from the fore-edge to the back-edge of the southern Taoyuan Terrace (surface A) reported by Lin et al. (2005), i.e., the transition from homogeneous to mottled and finally to gley soils, also exists on the spindle-shaped surface B. Reworked soils occur along riverbanks on surface $B$, while non-reworked homogeneous soils are dominant south of Lungtan. Nevertheless, such a pattern is not observed for the narrow, spindleshaped surface $\mathrm{C}$, within which randomly distributed mottled soils are found.

2) Mottled soils are dominant on surfaces $D$ and $E_{a}$, both of which are located in the northern distal fan area and have broad fan shapes. Large patches of homogeneous red soils occur near the eastern terrace scarp of surface $\mathrm{D}$, but none is present on surface $E_{a}$. The fore-edge of surface $E_{a}$ contains mottled and gley soils. A narrow band of homogeneous red soil occurs along the coast on surfaces D and $E_{a}$, approximately parallel to the seaward sandy soils.
3) The elevated surfaces $E_{b 1}-E_{b 3}$ have homogeneous soil almost entirely. Surface $E_{b 1}$, the lowest of the three surfaces, has the largest area of capping soils, with homogeneous red soil coexisting with orange and yellow soils. The other two surfaces contain only sporadic remnant flats that are overlain by homogeneous red soils.

It seems reasonable to expect that homogeneous red soil would occur on tectonically elevated surfaces and that mottled or gley soils would occur within low areas bordered by the highlands. Nevertheless, the following points demonstrate that the spatial distribution of soils developed on tectonically deformed landforms, as revealed by the map, are more complicated.

1) Among the elevated and tilted surfaces bordered by tectonic scarps 1-1 and 1-2, surfaces $\mathrm{D}_{1}$ and $\mathrm{E}_{\mathrm{a} 1}$ are mainly covered by homogeneous red soil with areas of reworked or mottled soils that increase toward the north. In contrast, surface $\mathrm{B}_{1}$, which records the lowest altitude and scarp height among all the elevated surfaces, contains a large area of gley soil that coexists with homogeneous red soil without systematic spatial variation. Surface $B_{2}$, bounded by scarp 1-3 to the north, is also dominated by homogeneous red soil. Within the eastern Yangmei Lowland, the soils change from homogeneous red soil to mottled soil and then to gley soil from south to north. Such a pattern is less obvious in the western sector of the Yangmei Lowland, where homogeneous red soils occupy both the fore-edge area along scarp IV and the exits of the rivers. The gley soils only dominate in the western end of the lowland where scarps 1-2 and 1-3 converge, with the proportion of 

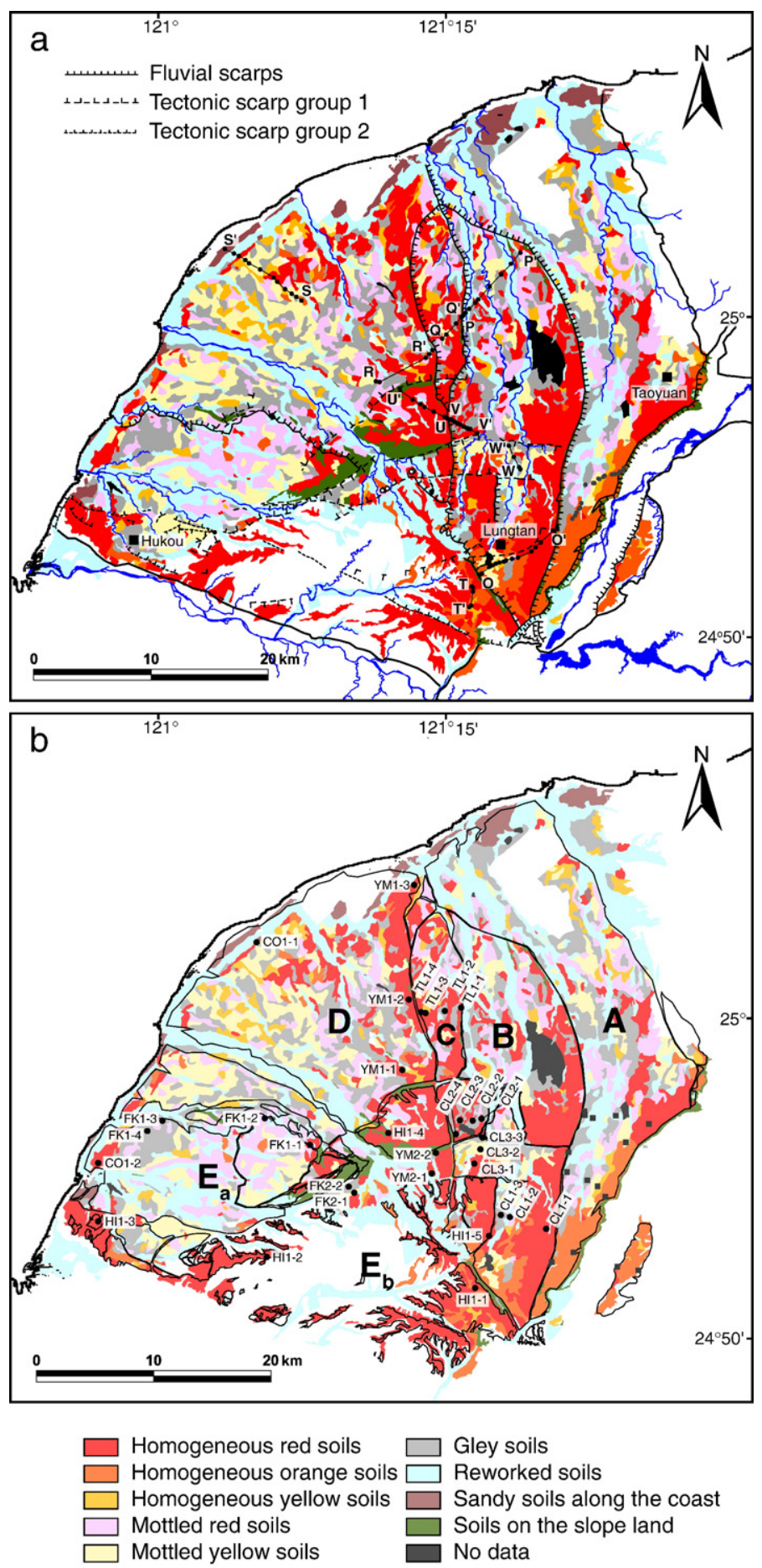

Fig. 3. Soil map of the Taoyuan-Hukou Tableland, reclassified from Chen (1976). (a) Engineering boreholes used in this study (black dots) and in Lin et al. (2005) (gray dots). (b) Ten groups of soil sampling sites used in this study (black dots) and in Lin et al. (2005) (gray squares).

gley soils increasing northward. The western Yangmei Lowland is also characterized by abundant reworked soils.
2) In the western part of surface $E_{b 3}$, homogeneous red soil covers the elevated area, whereas the reworked and gley soils overlie the surrounded area bordered 
by scarps 2-1-a and 2-1-b. The proportion of gley soil increases toward the coast.

\subsection{Spatial patterns of soil morphology inferred from field data}

The 32 sites for which we have soil morphological data collected from fieldwork and previously published studies can be divided into 10 groups (CL1, CL2, CL3, TL1, YM1, YM2, FK1, FK2, HI1, and CO1) based on their locations (Fig. 3b). Table 3 lists the morphological characteristics of selected soil profiles. Because of the large amount of data, we will focus on the major spatial patterns revealed within each group and compare field records with the soil map.

Morphological data from CL1-1 to CL1-3 confirm that the toposequence of homogeneous red soil to mottled soil and then to gley soil, a characteristic pattern in the southern part of surface A, is repeated in the broad, spindle-shaped surface B. For the narrow, spindle-shaped surface $\mathrm{C}$, field data reveal a different picture from that indicated by the soil map. The retrieved soil types from TL1-1, TL1-3, and TL1-4 are in good agreement with the soil map; however, at TL12 , where a moderate-sized area of gley soils was mapped, we found only homogeneous red soil.

We established two groups of sampling sites on the fan-shaped surfaces $\mathrm{D}$ and $\mathrm{E}_{\mathrm{a}}$ to examine the morphology of soils along the fore-edge, as this is a potential factor with which terraces are correlated (Lin et al., 2005). As shown on the soil map, the profiles at YM1-1 to YM1-3 are all characteristic homogeneous red soils. The soils at FK1-1 to FK1-3 are also homogeneous red soils rather than mottled red soils. Soils at site FK1-4, approximately $1.5 \mathrm{~km}$ from the terrace fore-edge, display the characteristics of mottled red soils rather than gley soils. We also examined the narrow band of homogeneous red soils located along the coast on surfaces $\mathrm{D}$ and $\mathrm{E}_{\mathrm{a}}$ at sites $\mathrm{CO} 1-1$ and CO1-2. The component soil series 'Pc' (Table 1) recorded on the map is said to contain a homogeneously red matrix and clayey texture. While the soil at site CO1-2 is typical of those of the Pc series, the soil at site CO1-1 displays the predicted color pattern but with sandy texture, even in the B horizon. According to Chen (1976), such characteristics are indicative of a different soil series, $\mathrm{Kz}$, which is divided into group 8 in our reclassification.

Profiles at HI1-1 to HI1-5 collected from elevated surfaces $\mathrm{B}_{2}, \mathrm{D}_{1}, \mathrm{E}_{\mathrm{b} 1}$, and $\mathrm{E}_{\mathrm{b} 3}$ all contain homogeneous red soil as the major soil type. In contrast, for surface $\mathrm{B}_{1}$, the lowest surface deformed by the Pingchen Anticline (Wang, 2003), field records at CL2-2 and CL2-4 confirm the existence of gley soils juxtaposed with homogeneous red soils.

The locations of three groups of sites, CL3, YM2, and FK2, were designed to investigate variations in soil morphology within the Yangmei Lowland. Soils at CL3-1 have a red matrix with few mottles in the $150 \mathrm{~cm}$ profile. Soils at CL3-2 have a yellow matrix and well-developed mottles throughout most of the B horizon. The bottom $30 \mathrm{~cm}$ of the CL3-2 profile, however, is actually a gley horizon. Soils at CL3-3 do not contain any red clods and are typical gley soils. Unlike the completely clayey soils at the CL3 sites, some soils at sites in the western Yangmei Lowland are clearly sandy. Soils at site YM2-1, for example, are predominantly sandy and brittle. The morphology of these soils varies from an orange matrix without observable mottles in the upper $100 \mathrm{~cm}$ to a red matrix with yellow mottles at lower depths. Soils at YM22 consist of a thick organic A horizon and a gley horizon underlain by a thick, compact plinthite. The upper gley horizon may have resulted from perennially perching water at the contact between the two layers with contrasting textures (Bohn et al., 1985). Soils at FK2-1 have a yellow matrix with red and black mottles, while soils at FK2-2 are sandy and gley. The alternation of sandy and clayey horizons in the FK2-2 profile indicates at least two depositional events. Despite the variable nature of soil texture within the western Yangmei Lowland, the northward transition from mottled to gley soils is observed in both groups. We did not drill for soil samples in the Hukou Lowland because most of the previously mapped pristine soils have been removed with the construction of an industrial park.

To summarize, the spatial pattern of soil morphology inferred from field records generally supports observations based on the soil map, except for surfaces $\mathrm{C}$ and $E_{a}$. The greater discrepancy between the field records and the soil map for these two surfaces is unusual, and indicates that the accuracy of the soil map varies across the Taoyuan-Hukou Tableland: the map is relatively accurate for surfaces $\mathrm{A}, \mathrm{B}, \mathrm{D}$, and $\mathrm{E}_{\mathrm{b}}$, but relatively inaccurate for surfaces $\mathrm{C}$ and $\mathrm{E}_{\mathrm{a}}$.

\section{Groundwater hydrology}

A total of 78 engineering boreholes, divided into nine groups (Fig. 3a), were used to construct geological cross-sections and the height of the groundwater table in different topographic settings. Profiles $\mathrm{O}-\mathrm{O}^{\prime}, \mathrm{P}-\mathrm{P}^{\prime}$ and Q- $\mathrm{Q}^{\prime}$ are located on the spindle-shaped surfaces $\mathrm{B}$ and $\mathrm{C}$ (Fig. $4 \mathrm{a}-\mathrm{c}$ ). The capping soils have been removed in their entirety at a number of boreholes close to channels (e.g., E53-1, PB69A, and PB80), reflecting the 
Table 3

Description of selected soil profiles based on field observations

\begin{tabular}{|c|c|c|c|c|c|c|c|c|}
\hline \multirow{2}{*}{$\begin{array}{l}\text { Depth } \\
(\mathrm{cm})\end{array}$} & \multirow[t]{2}{*}{ Horizon } & \multirow[t]{2}{*}{ Color } & \multicolumn{3}{|l|}{ Mottle $^{a}$} & \multirow[t]{2}{*}{ Texture $^{\mathrm{b}}$} & \multirow[t]{2}{*}{ Structure $^{\mathrm{c}}$} & \multirow[t]{2}{*}{ Consistence $^{\mathrm{d}}$} \\
\hline & & & Color & Quantity & Size & & & \\
\hline \multicolumn{9}{|l|}{ CL3-1 } \\
\hline $12-25$ & A & $10 \mathrm{YR} 3 / 6$ & 10YR2/1 & $\mathrm{f}$ & 1 & CL & gr-sbk & fi and BR \\
\hline $25-77$ & Bt1 & $5 \mathrm{YR} 4 / 6$ & n.d. ${ }^{\mathrm{e}}$ & - & - & $\mathrm{C}$ & sbk & fi and SD \\
\hline $77-149$ & Bt2 & $2.5 \mathrm{YR} 4 / 8$ & n.d. & - & - & $\mathrm{C}$ & sbk & fi and SD \\
\hline \multicolumn{9}{|l|}{ CL3-2 } \\
\hline $26-40$ & $\mathrm{~A} 1$ & $10 \mathrm{YR} 3 / 2$ & 7.5YR5/8 & $\mathrm{f}$ & 1 & $\mathrm{CL}$ & sbk & fr and SD \\
\hline $40-50$ & $\mathrm{~A} 2$ & 10YR4/6 & 7.5YR5/8 & $\mathrm{f}$ & 1 & CL & sbk & fr and SD \\
\hline $50-79$ & $\mathrm{Bt} 1$ & $10 \mathrm{YR} 5 / 8$ & $2.5 \mathrm{YR} 4 / 6$ & $\mathrm{~m}$ & 3 & $\mathrm{C}$ & sbk & fr and SD \\
\hline \multirow[t]{2}{*}{ 79-94 } & $\mathrm{Bt} 2$ & $2.5 \mathrm{Y} 7 / 2$ & $2.5 \mathrm{Y} 4 / 8$ & $\mathrm{~m}$ & 4 & $\mathrm{C}$ & $\mathrm{m}$ & vfr and D \\
\hline & & & $2.5 \mathrm{Y} 8 / 6$ & $\mathrm{c}$ & 2 & & & \\
\hline \multirow[t]{2}{*}{$94-124$} & Bt3 & $2.5 Y 5 / 8$ & $7.5 \mathrm{YR} 6 / 8$ & $\mathrm{~m}$ & 3 & $\mathrm{C}$ & sbk & fi and SD \\
\hline & & & 10YR7/1 & $\mathrm{m}$ & 3 & & & \\
\hline \multirow[t]{2}{*}{$124-140$} & $\mathrm{Bt} 4$ & 10YR7/8 & 10YR7/1 & $\mathrm{m}$ & 3 & $\mathrm{C}$ & sbk & fi and SD \\
\hline & & & $2.5 \mathrm{YR} 5 / 8$ & $\mathrm{f}$ & 1 & & & \\
\hline \multirow[t]{2}{*}{$140-170$} & Bt5 & 10YR7/8 & 10YR7/1 & $\mathrm{m}$ & 3 & $\mathrm{C}$ & $\mathrm{m}$ & fr and SD \\
\hline & & & $2.5 \mathrm{YR} 5 / 8$ & $\mathrm{f}$ & 1 & & & \\
\hline $170-196$ & $\mathrm{Bg}$ & 7.5YR6/1 & n.d. & - & - & $\mathrm{C}$ & $\mathrm{m}$ & fr and D \\
\hline \multicolumn{9}{|l|}{$C L 3-3$} \\
\hline $0-70$ & A & $10 \mathrm{YR} 4 / 4$ & 7.5YR5/8 & $\mathrm{f}$ & 1 & CL & sbk & fi and SD \\
\hline $70-97$ & $\mathrm{Bt}$ & 10YR3/1 & $7.5 \mathrm{YR} 3 / 4$ & $\mathrm{f}$ & 1 & $\mathrm{C}$ & $\mathrm{m}$ & fr and D \\
\hline $97-144$ & $\mathrm{Bg}$ & 10YR7/1 & n.d. & - & - & $\mathrm{C}$ & $\mathrm{m}$ & fr and D \\
\hline $14-146$ & $\mathrm{C}$ & 10YR7/1 & n.d. & - & - & L-SL & $\mathrm{m}$ & fr and D \\
\hline \multicolumn{9}{|l|}{$Y M 2-1$} \\
\hline $11-40$ & A & 10YR3/6 & n.d. & - & - & $\mathrm{L}$ & gr & lo \\
\hline $40-95$ & Bt1 & 7.5YR4/4-6 & n.d. & - & - & C-CL & sbk & vfr \\
\hline $95-110$ & $\mathrm{Bt} 2$ & 7.5YR4/4 & $2.5 \mathrm{YR} 4 / 8$ & $\mathrm{c}$ & 3 & C-CL & sbk & vfr \\
\hline $110-131$ & Bt3 & $2.5 Y 7 / 6$ & $2.5 \mathrm{Y} 4 / 8$ & $\mathrm{~m}$ & 4 & C-CL & sbk & vfr \\
\hline $131-149$ & Bt4 & 5YR5/6 & $2.5 \mathrm{Y} 7 / 6$ & $\mathrm{f}$ & 2 & $\mathrm{C}$ & sbk & vfr \\
\hline \multicolumn{9}{|l|}{$Y M 2-2$} \\
\hline $10-32$ & A & $2.5 \mathrm{Y} 3 / 2$ & $2.5 \mathrm{YR} 4 / 8$ & $\mathrm{f}$ & 2 & $\mathrm{C}$ & $\mathrm{m}$ & vfr and D \\
\hline \multirow[t]{2}{*}{$32-58$} & $\mathrm{Bg}$ & $2.5 Y 7 / 1$ & $2.5 \mathrm{YR} 4 / 8$ & $\mathrm{~m}$ & 3 & $\mathrm{C}$ & sbk & vfr and SD \\
\hline & & & $2.5 \mathrm{Y} 7 / 6$ & $\mathrm{c}$ & 3 & & & \\
\hline $58-66$ & Bt1 & $2.5 \mathrm{Y} 7 / 1$ & $2.5 \mathrm{YR} 4 / 8$ & $\mathrm{~m}$ & 3 & $\mathrm{C}$ & $\mathrm{m}$ & vfr and D \\
\hline $66-76$ & $\mathrm{Bt} 2$ & $2.5 \mathrm{YR} 4 / 8$ & $2.5 \mathrm{Y} 8 / 1$ & $\mathrm{f}$ & 2 & $\mathrm{C}$ & sbk & $\mathrm{fi}$ \\
\hline \multirow[t]{2}{*}{$76-170$} & $\mathrm{Bt} 3$ & $5 \mathrm{YR} 5 / 8$ & $2.5 Y 8 / 1$ & $\mathrm{~m}$ & 4 & $\mathrm{C}$ & sbk & fi \\
\hline & & & $2.5 \mathrm{Y} 8 / 6$ & $\mathrm{f}$ & 2 & & & \\
\hline $170-198$ & $\mathrm{C}$ & 7.5YR6/8 & $2.5 \mathrm{Y} 4 / 8$ & $\mathrm{f}$ & 2 & $\mathrm{~S}$ & $\mathrm{~m}$ & Lo \\
\hline $198-216$ & $2 \mathrm{Bt}$ & 7.5YR6/8 & $2.5 \mathrm{Y} 8 / 1$ & $\mathrm{f}$ & 2 & $\mathrm{C}$ & sbk & fr and SD \\
\hline \multicolumn{9}{|l|}{ FK2-1 } \\
\hline $9-14$ & A & $4 \mathrm{~N}$ & 10YR6/8 & $\mathrm{f}$ & 3 & $\mathrm{C}$ & abk & fi and SD \\
\hline & & & $2.5 \mathrm{YR} 5 / 8$ & $\mathrm{f}$ & 1 & & & \\
\hline $14-44$ & B1 & 10YR6/6 & $2.5 \mathrm{YR} 5 / 8$ & $\mathrm{c}$ & 3 & $\mathrm{C}$ & sbk & vfr and D \\
\hline & & & $2.5 \mathrm{Y} 8 / 3$ & $\mathrm{~m}$ & 3 & & & \\
\hline 44-97 & B2 & 10YR6/6 & $2.5 \mathrm{YR} 5 / 8$ & $\mathrm{~m}$ & 4 & $\mathrm{C}$ & sbk & vfr and D \\
\hline & & & $2.5 \mathrm{Y} 8 / 3$ & $\mathrm{c}$ & 2 & & & \\
\hline $97-122$ & B3 & $2.5 Y 7 / 8$ & 5YR5/8 & $\mathrm{c}$ & 3 & CL & sbk & fr and SD \\
\hline & & & $2.5 \mathrm{Y} 8 / 1$ & $\mathrm{c}$ & 3 & & & \\
\hline 122 & $\mathrm{C}$ & & & & & & & \\
\hline FK2-2 & & & & & & & & \\
\hline
\end{tabular}


Table 3 (continued)

\begin{tabular}{|c|c|c|c|c|c|c|c|c|}
\hline \multirow{2}{*}{$\begin{array}{l}\text { Depth } \\
(\mathrm{cm})\end{array}$} & \multirow[t]{2}{*}{ Horizon } & \multirow[t]{2}{*}{ Color } & \multicolumn{3}{|l|}{ Mottle $^{a}$} & \multirow[t]{2}{*}{ Texture $^{\mathrm{b}}$} & \multirow[t]{2}{*}{ Structure $^{\mathrm{c}}$} & \multirow[t]{2}{*}{ Consistence $^{\mathrm{d}}$} \\
\hline & & & Color & Quantity & Size & & & \\
\hline $0-34$ & 1B & $2.5 \mathrm{Y} 3 / 3$ & n.d. & - & - & $\mathrm{C}$ & abk & fi \\
\hline $34-90$ & $1 \mathrm{C}$ & $8 \mathrm{~N}$ & $2.5 Y 7 / 8$ & $f$ & 1 & $\mathrm{~S}$ & $\mathrm{~m}$ & lo \\
\hline $90-97$ & $2 \mathrm{~B}$ & $5 \mathrm{~N}$ & n.d. & - & - & $\mathrm{C}$ & sbk & fi and SD \\
\hline $97-162$ & $2 \mathrm{C}$ & $8 \mathrm{~N}$ & n.d. & - & - & $\mathrm{S}$ & $\mathrm{m}$ & lo \\
\hline \multicolumn{9}{|l|}{$F K 1-2$} \\
\hline $0-20$ & $\mathrm{~A} 1$ & $2.5 \mathrm{Y} 4 / 2$ & $10 \mathrm{YR} 5 / 8$ & $\mathrm{c}$ & 1 & $\mathrm{C}$ & gr-sbk & fr and BR \\
\hline $20-26$ & $\mathrm{~A} 2$ & 10YR4/4 & n.d. & - & - & $\mathrm{C}$ & sbk & fr and SD \\
\hline $26-37$ & B1 & 7.5YR5/8 & n.d. & - & - & $\mathrm{C}$ & sbk & fr and SD \\
\hline $37-130$ & $\mathrm{~B} 2$ & $2.5 \mathrm{YR} 4 / 6$ & n.d. & - & - & $\mathrm{C}$ & sbk & fr and SD \\
\hline 130 & $\mathrm{C}$ & & & & & & & \\
\hline \multicolumn{9}{|l|}{ CO1-1 } \\
\hline $0-35$ & A & 7.5YR4/4 & n.d. & - & - & SL & gr & vfr and SD \\
\hline $35-57$ & B1 & $5 \mathrm{YR} 4 / 4$ & n.d. & - & - & SL & $\mathrm{gr}$ & vfr and SD \\
\hline $57-85$ & B2 & $2.5 \mathrm{YR} 3 / 6$ & n.d. & - & - & $\mathrm{S}$ & sbk & fr and SD \\
\hline $85-105$ & B3 & $2.5 \mathrm{YR} 4 / 8$ & $2.5 \mathrm{YR} 3 / 3$ & $\mathrm{~m}$ & 3 & $\mathrm{~S}$ & sbk & fr and SD \\
\hline \multicolumn{9}{|l|}{$\mathrm{CO}-2$} \\
\hline $0-30$ & A & $2.5 \mathrm{YR} 4 / 8$ & n.d. & - & - & SL & $\mathrm{gr}$ & fi and BR \\
\hline $30-70$ & B1 & $2.5 \mathrm{YR} 4 / 6$ & n.d. & - & - & CL & sbk & fr and SD \\
\hline $70-100$ & B2 & $5 \mathrm{YR} 4 / 6$ & n.d. & - & - & CL & sbk & fr and SD \\
\hline
\end{tabular}

influence of fluvial processes. The three profiles indicate that local variations in the substratum, including the thickness of cobble layers and the proportion of illuviated clay in the matrix of the upper cobble layers (B56-1 and B54-1 in profile $\mathrm{O}-\mathrm{O}^{\prime}$ ), rarely affect the height of the groundwater table. The groundwater table is basically deeper at the fore-edge areas of these profiles and shallows toward the back-edge areas in profiles $\mathrm{O}-\mathrm{O}^{\prime}$ and $\mathrm{P}-\mathrm{P}^{\prime}$. Profile $\mathrm{O}-\mathrm{O}^{\prime}$ obliquely intercepts scarp 1-4 between boreholes B56-2 and C55-1, where the groundwater table is deeper than that in adjacent areas and indicative of lateral groundwater leakage through the tectonic scarp. The fact that the groundwater table largely follows surface topography in the spindleshaped terraces is in good agreement with the inferred groundwater table in surface A (Lin et al., 2005).

Profile $R-R^{\prime}$ stretches from the fore-edge to the middle of the broad, fan-shaped surface D (Fig. 4d). The fore-edge area has the highest elevation of the entire profile, indicating either significant surface erosion except for the fore-edge area and/or westward tectonic tilting that has arisen from asymmetric folding. The groundwater table is close to the surface in the middle of the broad fan, but is deeper in the fore-edge. The NWSE trending profile $\mathrm{S}-\mathrm{S}^{\prime}$ provides an opportunity to examine the topographic and groundwater conditions of the narrow band of red soils along the coastal parts of surface D (Fig. 4e). Some boreholes (A-1 and A-4) near the coast have a sandy capping layer, implying aeolian effect on fluvial sediments, a pervasive process in the coastal areas of northwest Taiwan (Yang, 2004). The inferred groundwater table is generally at approximately $2 \mathrm{~m}$ in depth, and does not show any significant anomaly with respect to topography or substratum type.

Profiles $T-\mathrm{T}^{\prime}, \mathrm{U}-\mathrm{U}^{\prime}$ and $\mathrm{V}-\mathrm{V}^{\prime}$ are located on the elevated surfaces $E_{b 1}, D_{1}$ and $B_{1}$, respectively (Fig. $4 f-h$ ). In profile $T-\mathrm{T}^{\prime}$, the groundwater table is generally deeper than $5 \mathrm{~m}$. The thick soil layers evident in the borehole data are consistent with those described in an earlier study (Lin, 1991). In contrast, in profile $U-U^{\prime}$ on surface $D_{1}$, the groundwater table is close to the surface except for those areas along the terrace edges. On the lowest surface, $\mathrm{B}_{1}$, profile $\mathrm{V}-\mathrm{V}^{\prime}$ has displayed similar substratum but complex topography and groundwater table. The topography undulates significantly from the fore-edge to the back-edge, and the groundwater table is $\sim 5 \mathrm{~m}$ deep in the 
fore-edge area $(\mathrm{C}-1)$. In depressions such as the area bracketed by sites $\mathrm{BH}-28$ and $\mathrm{BH}-32 \mathrm{~A}$, the groundwater table does not approach the surface, but is as deep as $\sim 4 \mathrm{~m}$. Even in the depression close to the back-edge (BH16 and $\mathrm{BH}-17 \mathrm{~A})$, the depth of the groundwater table is $\sim 2 \mathrm{~m}$.

\section{a Proximal area of surface B}

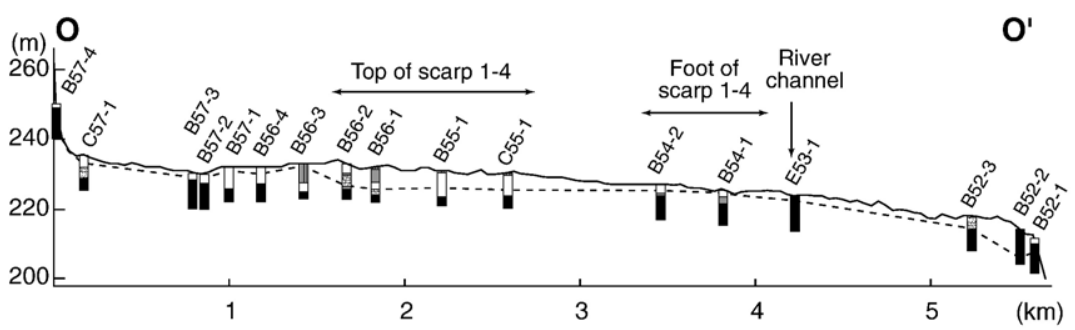

b Distal area of surface B

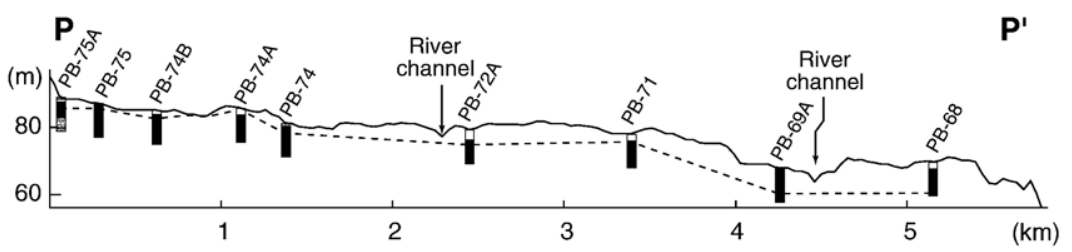

C Surface C

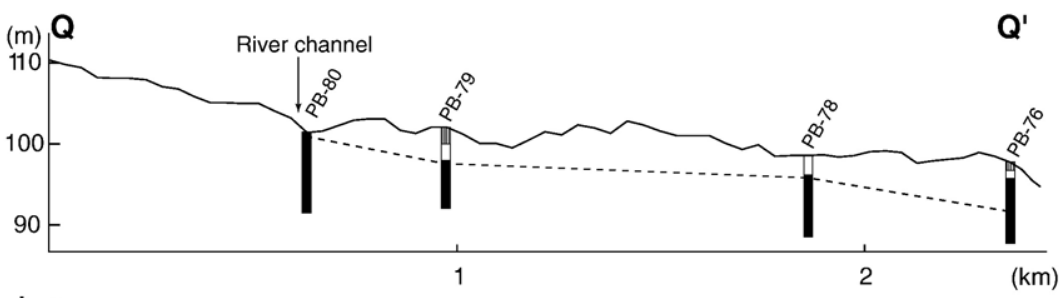

d Surface D

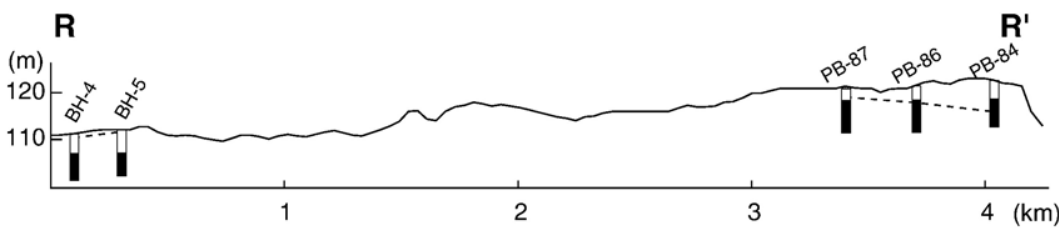

e Coastal area of surface D
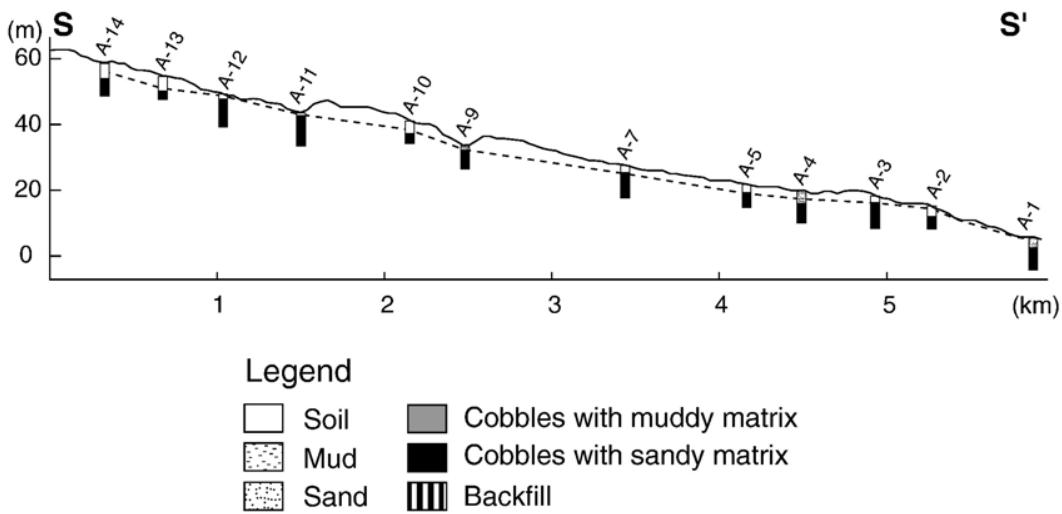

Fig. 4. Topographic profiles, shallow-subsurface geological profiles and groundwater tables inferred from engineering borehole data (dashed lines). See Fig. 3a for profile locations. 


\section{$f$ Surface $E_{b 1}$}
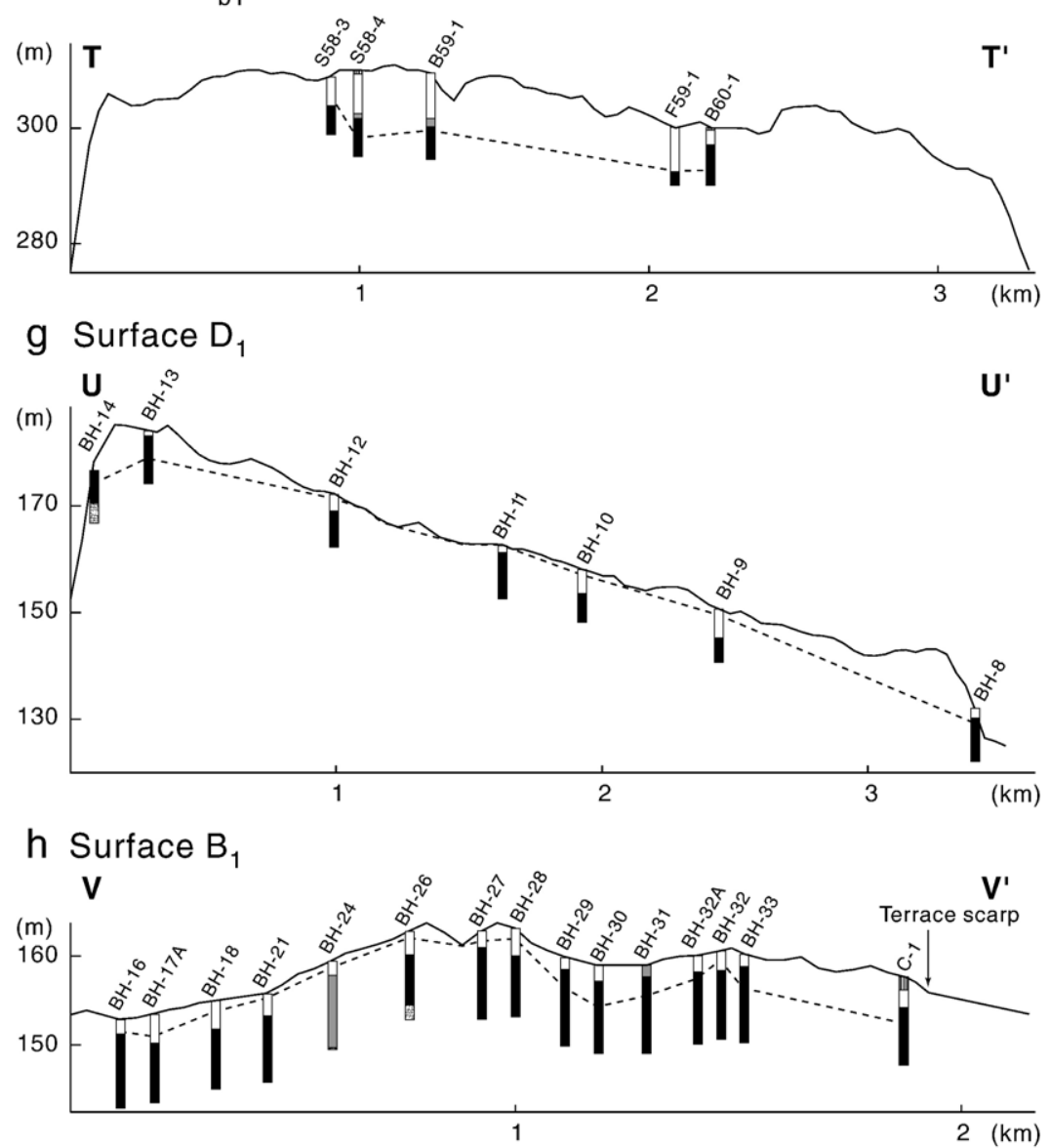

i Yangmei Lowland

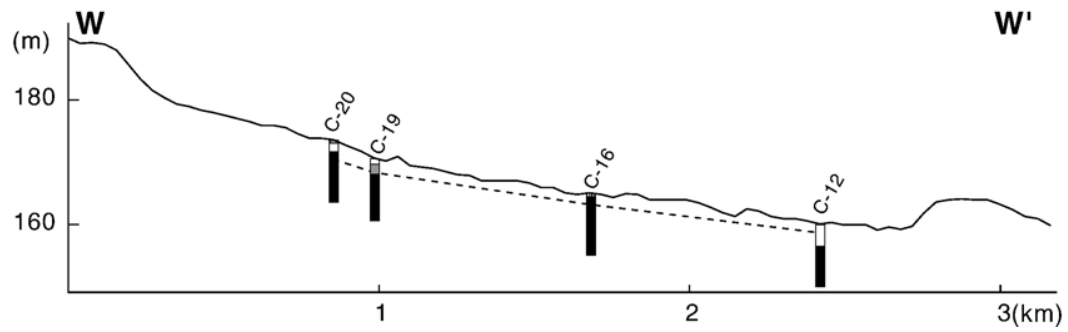

Fig. 4 (continued).

Boreholes along profile $\mathrm{W}-\mathrm{W}^{\prime}$, located within the eastern Yangmei Lowland, contain similar substratum (Fig. 4i). The slope of this northward-inclined lowland is $\sim 1 \%$. Coincidently, the groundwater table changes in depth from $\sim 3 \mathrm{~m}$ at $\mathrm{C}-20$ in the south to $\sim 1 \mathrm{~m}$ at $\mathrm{C}-12$ in the north. A number of boreholes obtained along the foot of scarp 1-3 in the western Yangmei Lowland (open circles in Fig. 3a) also record the groundwater table at ca. $3 \mathrm{~m}$ in depth.
The soil wetness pattern of the western Yangmei Lowland modeled using Eq. (1) (Fig. 5b) is in good agreement with that indicated by the reclassified soil map (Fig. 5a). Soils along the foot of scarp 1-2 have higher wetness values than those along the southern edge of the lowland. In the western part of the lowland, where scarps 1-2 and 1-3 converge to form a wedge-like landform, the proportion of areas with high wetness values increases significantly (the left-hand rectangles in 


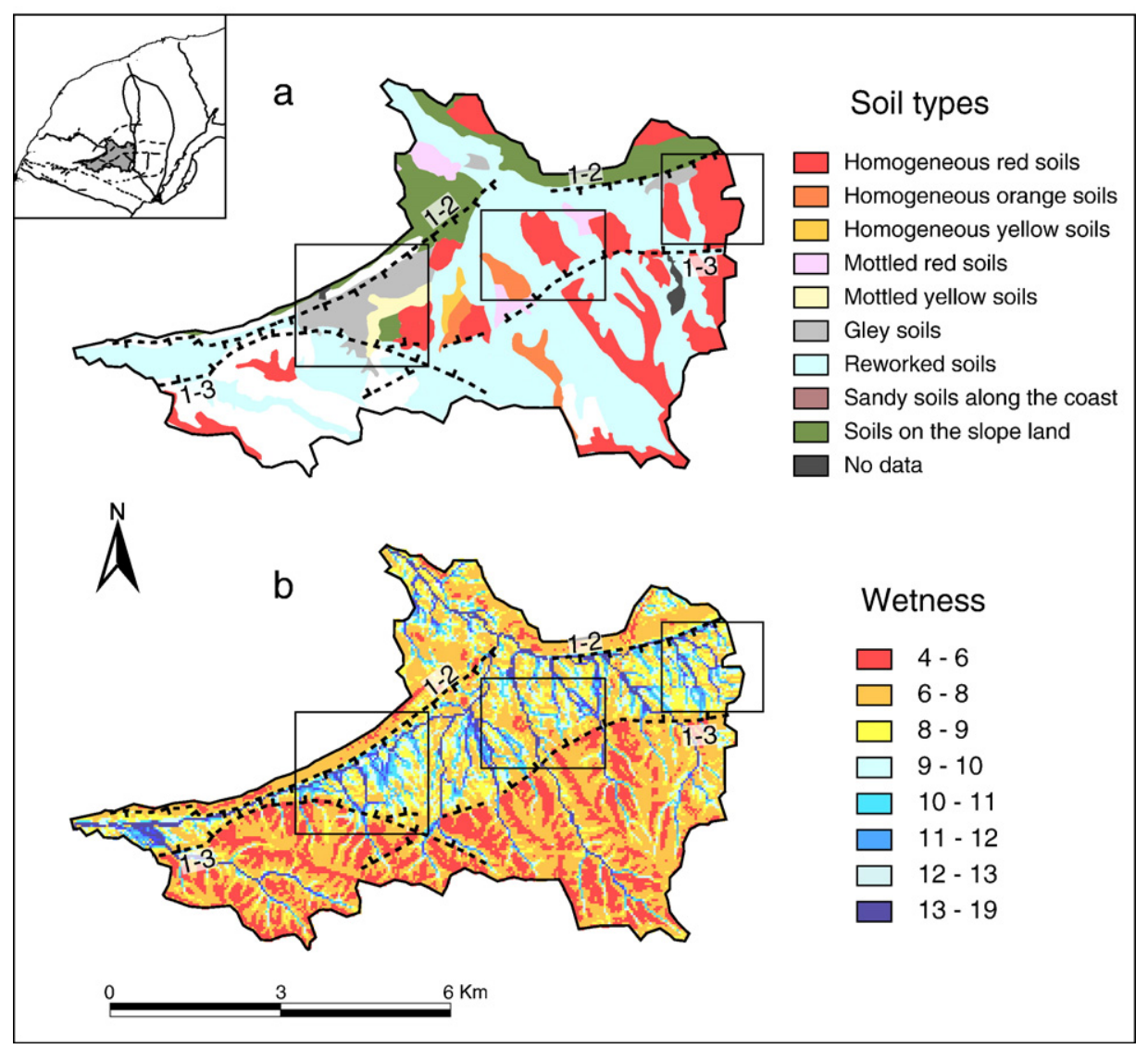

Fig. 5. Distribution of soils and soil wetness in the western Yangmei Lowland. (a) Reclassified soil map. (b) Simulated soil wetness pattern. Higher wetness values usually correspond to higher local soil-water content. The squares in (a) and (b) label specific soil morphology-wetness relationships discussed in the text. Dashed lines denote location of the tectonic scarps.

Fig. 5). In contrast, an area of low wetness extends across the middle section of the lowland where rivers exit to the north because of a lack of blocking highlands (the middle rectangles in Fig. 5). On approaching the eastern boundary of the catchment, i.e., terrace scarp IV (the right-hand rectangles in Fig. 5), the model results become progressively less reliable. As the model uses a simple relationship to approximate the relative wetness upon a continuously undulating surface, the discontinuity in slope along the scarps creates an edge effect that prevents the model from emulating the rapid drainage that occurs on the scarp face. Consequently, the simulated soil wetness for terrace surfaces adjacent to scarps tends to be overestimated.

The soil wetness of the Hukou Lowland was also simulated, but the results are not presented here because the construction of an industrial park and a highway strongly modified the surface relief, which in turn resulted in the generation of a chaotic wetness pattern.

\section{Discussion}

\subsection{Patterns of soil distribution upon spindle- and fan- shaped surfaces}

The patterns of soil distribution on surface B inferred from the reclassified soil map and field records are in good agreement, and indicate that from the fore-edge to the back-edge of the broad, spindle-shaped terrace, soils change systematically from homogeneous red soils to mottled soils and finally to gley soils. Such a soil toposequence was previously reported in other topographic settings (e.g., Lin et al., 2005; Thanachit et al., 2006), for which the topographically determined groundwater distribution was considered to govern the observed variation in soil morphology. As the groundwater distributions in the proximal and distal parts of surface B (Fig. 4a,b) display similar trends to that on surface $A$, the observed soil toposequences are 
considered to have formed from a common mechanism; that is, different drainage conditions and corresponding pedogenetic processes between the back- and fore-edges controlled by the lateral recharge and discharge of groundwater.

On the narrow, spindle-shaped surface $\mathrm{C}$, the failure to recover gley soils indicates a discrepancy between the soil-distribution patterns inferred from the soil map and those indicated from field data. According to the profile reconstructed from engineering borehole data (Fig. 4c), the groundwater table is deeper than $2 \mathrm{~m}$ to the east of PB-79, which is located in the middle of the surface. On the basis of inferred drainage conditions, the field records appear to be more reliable than the soil map. The occurrence of homogeneous red soils in the back-edge area (confirmed by both the soil map and field data) indicates that soils in this area should also be well drained. Therefore, soils on surface $\mathrm{C}$, which should be older than the 30 kyr-old surface A (Chen and Liu, 1991), were probably mainly homogeneous red soils until the last glacial period when the climate was relatively arid (Liew et al., 2006). During the relatively humid Holocene, increased precipitation and runoff interrupted latosolization, producing sporadic mottling and gley soils along the channels. Khan et al. (2005) also reported degraded argillans and ferriargillans in soils older than $15 \mathrm{ka}$ during the later hot humid to subhumid climate. Nevertheless, the narrower E-W width of surface $\mathrm{C}$ makes the lateral discharge efficient, helping to preserve homogeneous soils within the back-edge.

Compared with the systematic variations in soil morphology observed on the spindle-shaped terraces, soil-distribution patterns for the fan-shaped surfaces D and $E_{a}$ are nearly random except for in the fore-edge areas. The homogeneous red soils on the fore-edge of surface $\mathrm{D}_{1}$, confirmed by field records, reflect efficient discharge as inferred from profile $\mathrm{R}-\mathrm{R}^{\prime}$ (Fig. $4 \mathrm{~d}$ ). We also recovered homogeneous red soils from the foreedge of surface $E_{a}$. Although there are no engineering borehole data available in terms of the depth of the groundwater table in this area, it is reasonable to expect a deep groundwater table in the fore-edge, and this facilitates the formation of homogeneous red soils. The absence of any systematic variation in soil morphology and the prevalence of mottled soils in both fan-shaped surfaces indicate that most of the soils are seasonally saturated, alternating between oxic and suboxic regimes. This interpretation is supported by the results of longterm monitoring of the groundwater table beneath surface D (Hseu and Chen, 2001). Factors to hinder efficient groundwater discharge in both surfaces include the geometry of a broad fan shape and their distal location within the paleo-fan, which is characterized by a larger watershed area and finer alluvium texture.

Our field investigations confirm the existence of a narrow band of red soils along the coastal margins of surfaces $\mathrm{D}$ and $\mathrm{E}_{\mathrm{a}}$. In contrast to typical homogeneous red soils, however, some soils have sandier textures. The geological cross-section for this area (Fig. 4e) indicates a lack of topographic or groundwater anomalies at core site A-3, where the red soils occur. We therefore ruled out the possibility that these red soils developed because of deeper groundwater levels controlled by topographic features. It is likely that the sandier texture of these soils, rather than topography, plays a greater role in forming homogeneous red soils (Ensign et al., 2006). Further study is required to clarify the formation of these coastal red soils.

\subsection{Patterns of soil distribution within tectonically elevated surfaces}

Tectonically elevated surfaces can be divided into three groups: the highest and severely dissected surfaces $\mathrm{E}_{\mathrm{b}}$, the lower and more intact surfaces $\mathrm{D}_{1}$ and $\mathrm{E}_{\mathrm{a} 1}$, and surfaces $\mathrm{B}_{1}$ and $\mathrm{B}_{2}$ with neighboring highlands to the west. The field records confirm the dominance of homogeneous red soils in the first two groups, whereas the engineering borehole data show different patterns of groundwater table (Fig. $4 \mathrm{f}-\mathrm{h}$ ). For surface $\mathrm{E}_{\mathrm{b} 1}$, the groundwater table is generally deeper than $5 \mathrm{~m}$, implying that soils across the entire surface experience well-drained conditions. In contrast, the groundwater table beneath surface $D_{1}$ is very close to the surface except at the terrace edges; this accounts for the occurrence of mottled soils in the central part of surface $\mathrm{D}_{1}$. One explanation for the varied patterns of groundwater-table depth is the degree of terrace dissection. The more highly a surface is dissected, the higher its hydraulic gradient and consequently the higher its discharge efficiency.

The dominance of homogeneous red soils on surface $\mathrm{B}_{2}$ can be explained by the narrow $\mathrm{E}-\mathrm{W}$ width of the surface that facilitates groundwater discharge, as with the southern part of surface A. That the large patch of reworked soil upon the back-edge of surface $\mathrm{B}_{2}$ locates at the exits of the gullies originating from surface $\mathrm{E}_{\mathrm{b} 3}$ suggests that it is derived from the adjacent surface. Surface $\mathrm{B}_{1}$, with a similarly narrow $\mathrm{E}-\mathrm{W}$ width, lower elevation, and a more distal position relative to surface $\mathrm{B}_{2}$, displays a complex soil-distribution pattern. Gley soils occur within local depressions, beneath which the inferred groundwater table is as deep as $\sim 4 \mathrm{~m}$ (Fig. $4 \mathrm{~h}$ ). The reason for the discrepancy between the variations in 
soil morphology and inferred groundwater depths is unclear. Long-term field monitoring of the groundwater table is required to clarify the influence of groundwater on soil development in this area.

\subsection{Patterns of soil distribution within the regions surrounded by tectonically elevated surfaces}

The soil toposequence of homogeneous-mottled-gley soils that occur between the fore- and back-edges of broad, spindle-shaped terraces is repeated within the narrow, north-tilted Yangmei Lowland (Fig. 3). Field records confirm that from south to north, scarp soils change from homogeneous red soils to mottled soils and finally to gley soils, although this pattern is more prominent in the eastern sector of the Yangmei Lowland. In the western Yangmei Lowland where the bordering scarps are higher than their counterparts in the east, the higher proportion of reworked soils and increased recovery of sandy soils reflect the occurrence of extensive and frequent fluvial processes that act to interrupt soil formation.

The groundwater table inferred from engineering borehole data (Fig. 4i) in the eastern Yangmei Lowland displays a shallowing trend toward the north. In the simulated soil-wetness pattern for the western Yangmei Lowland (Fig. 5b), soils along the foot of the northern scarp have the highest wetness values $(>12)$, whereas those along the foot of the southern scarp record smaller values (6-9). These two lines of evidence support the proposition that variations in soil morphology reflect the drainage conditions, which is mainly controlled by scarp 1-2 located to the north. Although the degree of northward tilting $(1-2 \%)$ in the lowland is not significantly different from that of $\mathrm{N}-\mathrm{S}$ slopes recorded on other terrace surfaces, it helps to define the flow direction of surface water. Scarp 1-2 blocks the northward-flowing rivers and the surface water has more time to permeate into the soil. The large patch of homogeneous red soil developed at the exit of the Shetzu River, where the surface water is not blocked, supports this argument. Away from the river exit to the west where the $\mathrm{N}-\mathrm{S}$ width of the lowland is reduced, the drainage efficiency decreases even further, resulting in the dominance of gley soils.

The proportion of gley soils within the Hukou Lowland increases westward. Chen (1976) noted this unusual pattern and ascribed the presence of a large area of gley soil to a paleolake that drained via northwestward-flowing rivers. Although no information concerning the groundwater table is available for this area, it is possible that the mechanism that controls gleization in the western Yangmei Lowland, that is, a blocking highland in the distal direction, also plays a role in this region. Such an interpretation is supported by the similar topographic settings of the two lowlands.

\subsection{Implications for establishing soil-time relation- ships for the Taoyuan-Hukou Tableland}

Daniels et al. (1967) concluded that the characteristics of a soil depend on the length of time for which a site has been well drained rather than the age of the geomorphic surface. Lin et al. (2005) proposed that soils along the fore-edge of a terrace surface can be used to correlate terraces, as their optimal drainage conditions enable the development of time-dependent soil characteristics. In the present study, there are two observations related to the issue of soil-time relationships. First, we noticed a seemingly time-related trend of increased proportion of homogeneous red soils towards the older surfaces when surfaces $\mathrm{A}, \mathrm{B}, \mathrm{C}$ and $\mathrm{E}_{\mathrm{b}}$ group are taken into account, implying convergent soil evolution (Toomanian et al., 2006). Since initial topographic conditions (surface geometry, proximal-distal position and the existence of adjacent higher surface) also contribute to this pattern, proportion of homogeneous red soils cannot be used as a reliable proxy for relative ages of geomorphic surfaces. Second, all the surfaces contain fore-edge homogeneous red soils that usually decrease in area toward the distal region. Simple quantitative morphological indexes like the redness index have failed to resolve the chronological order of surfaces A to D (Lin, 1991), whereas composite morphological quantification like the profile development index has higher potential to provide sufficient temporal resolution based on its successful application on the Pakau river terraces aged 40-400 ka (Tsai et al., 2007, in press-b). Unfortunately, the rough, field-based description of soil morphology presented in this study does not enable correct calculation of the profile development index. The obvious next step is to collect soil samples from the proximal fore-edge area of each surface to establish a soil chronosequence and to see if the relative ages of the tectonically elevated surfaces can be thus bracketed. Such a sampling criterion for soil chronosequences should also apply to any other relict, multi-step alluvial fan surfaces.

\section{Conclusions}

This study has investigated the relationships between topography and spatial variations in groundwater and soil morphology within the Taoyuan-Hukou Tableland 
on the basis of an integrated geomorphological and pedological approach. The observed soil-distribution patterns, each of which is associated with a unique set of topographic and hydrological conditions, can be summarized as follows.

1) Drainage efficiency increases with progressive narrowing of the terrace width, which in our study area refers to the E-W distance across a surface. Homogeneous and mottled soils dominate narrow and fanshaped surfaces, respectively, while moderate width leads to the development of a toposequence.

2) In terms of the locality of a surface with respect to the paleofan, the patterns described above are more pronounced in the proximal part of a surface, while toward the distal zone the patterns tend to be obscured by increasing amounts of mottled and gley soils.

3) As is evident from the occurrence of mottled soils within the central areas of some elevated surfaces, soils on an intact surface are more poorly drained than those on a highly dissected surface. Since the degree of terrace dissection is also controlled by time, many reasons exist for the dominance of homogeneous red soils on the most elevated surfaces.

4) Not all of the soils within the northward-tilted lowlands are gleyed: only those situated at the base of scarps blocking drainage to the distal direction show this character, reflecting the damming effect of the surrounding highlands.

Despite the observed pedodiversity, a common feature of these toposequences is the distribution of homogeneous red soils along the terrace fore-edge; this may serve as the basis for establishing a reliable soil chronosequence in the future.

\section{Acknowledgements}

We thank L.S. Teng and C.T. Lee for their encouragement and valuable comments. We also thank N.Y. Lin for assistance on ArcView operation and T.P. Chang, Y.F. Chang, L.T. Chen, S.W. Chiang and P.L. Lin for their help with our fieldwork. This study was supported by the NSC grants NSC92-2815-c-002-075-M to Y.W.L. and NSC902815-c-002-112-M to Y.W.

\section{References}

Beven, K.J., Kirkby, M.J., 1979. A physically based, variable contributing area model of basin hydrology. Hydrol. Sci. Bull. 24, 43-69.

Birkland, P.W., 1999. Soils and Geomorphology. Oxford, New York.
Bockheim, J.G., Marshall, J.G., Kelsey, H.M., 1996. Soil-forming processes and rates on uplifted marine terraces in southwestern Oregon, USA. Geoderma 73, 39-62.

Bohn, H.L., McNeal, B.L., O'Connor, G.A., 1985. Soil Chemistry. John Wiley \& Sons, New York.

Bullinger-Weber, G., Gobat, J.M., 2006. Identification of facies models in alluvial soil formation: the case of a Swiss alpine floodplain. Geomorphology 74, 181-195.

Central Weather Bureau, 1996-2005. Climatological Data Annual Report: Part I. Surface Data.

Chen, C.C., 1976. Soil Survey Report of Taoyuan County. Research Report, vol. 33. Institute of Agriculture, Taipei (in Chinese).

Chen, Y.G., 1988. Radiocarbon ages and terrace correlation of the fluvial terraces along the lower reach of the Tahan River. Master Thesis, Natl. Taiwan Univ., Taipei (in Chinese).

Chen, Y.G., Liu, T.K., 1991. Radiocarbon dates of river terraces along the lower Tahachi, Northern Taiwan: their tectonic and geomorphic implications. Proc. Geol. Soc. China 34, 337-347.

Chen, Y., Wang, Y., Hou, C., Chen, W., 2003. Active structure evolutions deduced from geomorphic and geodetic evidence, from Hsinchu to Taoyuan, Northwestern Taiwan. Eos Trans. AGU 84 (46) (Fall Meet. Suppl., T12C-0473).

Daniels, R.B., Gamble, E.E., Nelson, L.A., 1967. Relation between A2 horizon characteristics and drainage in some fine loamy Ultisols. Soil Sci. 104, 364-369.

Ensign, K.L., Webb, E.A., Longstaffe, F.J., 2006. Microenvironmental and seasonal variations in soil water content of the unsaturated zone of a sand dune system at Pinery Provincial Park, Ontario, Canada. Geoderma 136, 788-802.

Ho, C.S., 1986. A synthesis of the geologic evolution of Taiwan. Tectonophysics $125,1-16$.

Hseu, Z.Y., Chen, Z.S., 2001. Quantifying soil hydromorphology of a rice-growing ultisol toposequence in Taiwan. Soil Sci. Soc. Am. J. $65,270-178$.

Huang, S.C., 1995. The gravel deposits of Taoyuan Terraces. Master Thesis, Natl. Central Univ., Chungli (in Chinese).

Ibáñez, J.J., Pérez-González, A., Jiménez-Ballesta, R., Saldaña, A., Gallardo-Díaz, J., 1994. Evolution of fluvial dissection landscapes in Mediterranean environments. Quantitative estimates and geomorphological, pedological and phytocenotic repercussions. Z. Geomorphol. N.F. 38, 105-119.

Jien, S.H., Hseu, Z.Y., Chen, Z.S., 2004. Relations between morphological color index and soil wetness condition of anthraquic soils in Taiwan. Soil Sci. 169, 871-882.

Khan, M.S.H., Parkash, B., Kumar, S., 2005. Soil-landform development of a part of the fold belt along the eastern coast of Bangladesh. Geomorphology 71, 310-327.

$\mathrm{Ku}$, C.C., 1963. Photogeologic study of terraces in Northwestern Taiwan. Proc. Geol. Soc. China 6, 51-60.

Liew, P.M., Huang, S.Y., Kuo, C.M., 2006. Pollen stratigraphy, vegetation and environment of the last glacial and Holocene - a record from Toushe Basin, central Taiwan. Quat. Int. 147, 16-33.

Lin, C.C., 1957. Topography of Taiwan. Publ. of the Taiwan Provincial Documentary Committee, Taipei (in Chinese).

Lin, S.F., 1991. A preliminary red soil study on terraces in TaoyuanHukou area. Master Thesis, Natl. Taiwan Univ., Taipei (in Chinese).

Lin, Y.S., Chen, Y.G., Chen, Z.S., Hsieh, M.L., 2005. Soil morphological variations on the Taoyuan Terrace, Northwestern Taiwan: roles of topography and groundwater. Geomorphology 69, 138-151.

Lin, H.S., Kogelmann, W., Walker, C., Bruns, M.A., 2006. Soil moisture patterns in a forested catchment: a hydropedological perspective. Geoderma 131, 345-368. 
Lu, C.Y., Angelier, J., Chu, H.T., Lee, J.C., 1995. Contractional, transcurrent, rotational and extensional tectonics: examples from Northern Taiwan. Tectonophysics 125, 129-146.

Marcos, J.M.G., Frances, F.S., 1997. Relationship between the characteristics of Mediterranean red soils and the age of the geomorphological surfaces in central-western Spain. Catena 28, 231-245.

Muhs, D.R., 2001. Evolution of soils on Quaternary reef terraces of Barbados, West Indies. Quat. Res. 56, 66-78.

Phillips, J.D., 2001. Divergent evolution and the spatial structure of soil landscape variability. Catena 43, 101-113.

Saldaña, A., Ibáñez, J.J., 2004. Pedodiversity analysis at large scales: an example of three fluvial terraces of the Henares River (central Spain). Geomophpology 62, 123-138.

Saldaña, A., Stein, A., Zinck, J.A., 1998. Spatial variability of soil properties at different scales within three terraces of the Henares River (Spain). Catena 33, 139-153.

Schoeneberger, P.J., Wysocki, D.A., Benham, E.C., Broderson, W.D., 1998. Field Book for Describing and Sampling Soils. Natural Resources Conservation Service, USDA, National Soil Survey Center, Lincoln, NE.

Shyu, J.B.H., Sieh, K., Chen, Y.G., Liu, C.S., 2005. Neotectonic architecture of Taiwan and its implications for future large earthquakes. J. Geophys. Res. 110, B08402. doi:10.1029/2004JB003251.

Sun-Lin, Y.M., 1982. Geomorphology of the active faults in the Taoyuan tableland. Master Thesis, Natl. Taiwan Normal Univ., Taipei (in Chinese).

Suppe, J., 1981. Mechanics of mountain building and metamorphism in Taiwan. Mem. Geol. Soc. China 4, 67-89.

Suppe, J., 1983. Geometry and kinematics of fault-bend folding. Am. J. Sci. 283, 684-721.

Tarboton, D.G., 1997. A new method for the determination of flow directions and contributing areas in grid digital elevation models. Water Resour. Res. 33, 309-319.

Teng, L.S., 1990. Late Cenozoic arc-continent collision in Taiwan. Tectonophysics $183,57-76$.

Teng, L.S., 1996. Extensional collapse of the northern Taiwan mountain belt. Geology 24, 949-952.

Teng, L.S., Lee, C.T., 1996. Geomechanical appraisal of seismogenic faults in Northeast Taiwan. J. Geol. Soc. China 39, 125-142.

Teng, K.H., Tung, T.H., Chen, C.J., Yeh, P.S., 2003. A study on the relationship between Hokou active fault and its tectonic terraces, Taoyuan tableland. J. Taipei Munic. Teach. Coll. 34, 135-156 (in Chinese with English abstract).
Thanachit, S., Suddhiprakarn, A., Kheoruenromne, I., Gilkes, R.J., 2006. The geochemistry of soils on a catena on basalt at Khon Buri, northeast Thailand. Geoderma 135, 81-96.

Toomanian, N., Jalalian, A., Khademi, H., Eghbal, M.K., Papritz, A., 2006. Pedodiversity and pedogenesis in Zayandeh-rud Valley, Central Iran. Geomorphology 81, 376-393.

Tsai, H., Huang, W.S., Hseu, Z.Y., 2006. A river terrace soil chronosequence of the Pakua Tableland in central Taiwan. Soil Sci. 171, 167-179.

Tsai, H., Hseu, Z.Y., Huang, W.S., Chen, Z.S., 2007. Pedogenic approach to resolving the geomorphic evolution of the Pakua river terraces in central Taiwan. Geomorphology 83, 14-48.

Tsai, C.C., Tsai, H., Hseu, Z.Y., Chen, Z.S., in press. Soil pedogenesis along a chronosequence on marine terrace in eastern Taiwan. Catena.

Tsai, H., Huang, W.S., Hseu, Z.Y., in press. Pedogenic correlation of lateritic river terraces in central Taiwan. Geomorphology.

Wada, N., 2004. Composition change of soil clay minerals and free iron oxides with terrace development in North Taiwan. Master Thesis, Meiji Univ., Tokyo.

Wang, Y., 2003. Morphotectonics in Taoyuan-Hsinchu Area, Northwestern Taiwan. Master Thesis, Natl. Taiwan Univ., Taipei.

Wang, Y., Chen, Y., Shyu, J., Chuang, R., Lin, Y., Chung, L., 2002. The active tectonic features in Taoyuan Area, Northwestern Taiwan. Eos Trans. AGU 83 (47) (Fall Meet. Suppl., T62D-10).

Watanuki, T., Chen, Y.G., Chen, Y.W., 2005. Optically stimulated luminescence dating of river terraces in Taoyuan and Hsinchu areas, northwestern Taiwan. 11th Int. Conf. Luminescence and Electron Spin Resonance Dating, Cologne, Germany.

Wei, K., Chen, Y.G., Liu, T.K., 1998. Sedimentary history of the Taipei Basin with constraints from thermoluminescence dates. J. Geol. Soc. China 41, 109-125.

Woods, A.J., 1980. Geomorphology, deformation, and chronology of marine terraces along the Pacific Coast of Central Baja California, Mexico. Quat. Res. 13, 346-364.

Yang, G.X., 1986. Geomorphology of the active faults in Taiwan: relationship between active faults and geomorphic surfaces. $\mathrm{PhD}$ Thesis, Chinese Culture Univ., Taipei.

Yang, M.P., 2004. The study of the change of coastal landform in Taoyuan County. Master Thesis, Natl. Taiwan Univ., Taipei.

Yu, S.B., Chen, H.Y., Kuo, L.C., 1997. Velocity field of GPS stations in the Taiwan area. Tectonophysics 274, 41-59.

Zhou, Q., Liu, X., 2002. Error assessment of grid-based flow routing algorithms used in hydrological models. Int. J. Geogr. Inf. Sci. 16, 819-842. 